Article

\title{
On the Microstructure and Isothermal Oxidation of the Si-22Fe-12Cr-12Al-10Ti-5Nb (at.\%) Alloy
}

\author{
Ofelia Hernández-Negrete and Panos Tsakiropoulos * (D) \\ Department of Materials Science and Engineering, Sir Robert Hadfield Building, The University of Sheffield, \\ Mappin Street, Sheffield S1 3JD, UK; ochernandeznegrete@gmail.com \\ * Correspondence: p.tsakiropoulos@sheffield.ac.uk
}

Received: 23 April 2019; Accepted: 31 May 2019; Published: 3 June 2019

\begin{abstract}
Nb}$-silicide based alloys are new ultra-high temperature materials that could replace Ni-based superalloys. Environmentally resistant coating system (s) with $\alpha \mathrm{Al}_{2} \mathrm{O}_{3}$ or $\mathrm{SiO}_{2}$ forming bond coat alloys that are chemically compatible with the $\mathrm{Nb}$-silicide based alloy substrates are needed. This paper makes a contribution to the search for non-pesting bond coat alloys. The microstructure and isothermal oxidation at $800{ }^{\circ} \mathrm{C}$ of the silicide-based alloy Si-22Fe-12Cr-12Al-10Ti-5Nb (OHC2) were studied. The cast alloy exhibited macrosegregation of all elements. The microstructures in the cast alloy and after the heat treatment at $800{ }^{\circ} \mathrm{C}$ consisted of the same phases, namely $\mathrm{TM}_{6} \mathrm{Si}_{5}, \mathrm{TM}_{5} \mathrm{Si}_{3}$ ( $\mathrm{TM}=$ transition metal), $\mathrm{FeSi}_{2} \mathrm{Ti}_{1} \mathrm{Fe}_{3} \mathrm{Al}_{2} \mathrm{Si}_{3},(\mathrm{Fe}, \mathrm{Cr})(\mathrm{Si}, \mathrm{Al})$, and an unknown phase of dark contrast. The latter two phases were not stable at $950{ }^{\circ} \mathrm{C}$, where the $\mathrm{TMSi}_{2}$ was formed. There was evidence of endothermic reaction(s) below $1200{ }^{\circ} \mathrm{C}$ and liquation at $1200^{\circ} \mathrm{C}$. The alloy followed parabolic oxidation kinetics after the first hour of isothermal oxidation at $800^{\circ} \mathrm{C}$, did not pest, and formed a self-healing scale, in which the dominant oxide was $\mathrm{Al}_{2} \mathrm{O}_{3}$. The alloy was compared with other alumina or silica scale-forming intermetallic alloys and approaches to the design of bond coat alloys were suggested.
\end{abstract}

Keywords: coatings; intermetallics; silicides; pest oxidation; high temperature oxidation; $\mathrm{Nb}$-silicide based alloys

\section{Introduction}

Currently, Ni-based superalloys are the structural materials of choice for the aerofoils used in the hottest parts of gas turbine engines. Superalloy aerofoils are operated with environmentally resistant coatings and internal cooling, but even with these features their high temperature capability has reached a limit owing to the melting temperatures of $\mathrm{Ni}$ and Ni-based superalloys [1,2]. The aerospace industry needs power systems with better efficiency, which is achievable with increase of the turbine entry temperature. As the latter increases beyond $1500^{\circ} \mathrm{C}$, new high temperature materials will be required. These materials should have some inherent resistance to high temperature oxidation and good mechanical properties at room, intermediate, and high temperatures.

$\mathrm{Nb}$-silicide-based alloys (also known as $\mathrm{Nb}$-silicide in-situ composites) can offer a balance of properties [3]. A major challenge for the development of $\mathrm{Nb}$-silicide-based alloys is their oxidation, which can change from catastrophic at intermediate temperatures (pest oxidation) to complex at high temperatures [3]. Even though the oxidation has been dramatically improved without compromising their ductility, $\mathrm{Nb}$-silicide based alloys do not form a protective scale because the concentrations of the key elements $\mathrm{Al}, \mathrm{Cr}, \mathrm{Si}$, and $\mathrm{Ti}$ are restricted by property and melting temperature requirements.

The $\mathrm{Nb}$-silicide-based alloys would require environmentally resistant coatings, such as the Ni-based superalloys [1,2,4]. It is anticipated that $\mathrm{Nb}$-silicide-based alloy (substrate) surface temperatures could be up to 150 degrees higher compared with state of the art internally cooled and 
coated single crystal Ni-based superalloy aerofoils. This will only be possible using a materials system approach, where the latter will comprise the substrate, which should have some inherent oxidation resistance, and an environmentally resistant coating system. The latter could consist of bond coating and a ceramic thermal barrier. In other words, an environmentally resistant coating for $\mathrm{Nb}$-silicide based alloys could have a structure similar to that of the coatings used for Ni-based superalloys, namely an oxidation resistance bond coat (BC), thermally grown oxide (TGO), and ceramic top coat $[5,6]$. The TGO formed in situ in coated Ni-based superalloys is $\alpha \mathrm{Al}_{2} \mathrm{O}_{3}$. Research must find $\mathrm{BC}$ s that are compatible with $\mathrm{Nb}$-silicide based alloys that could form $\alpha \mathrm{Al}_{2} \mathrm{O}_{3}$ (preferred) or $\mathrm{SiO}_{2} \mathrm{TGO}$. This has been discussed in recent publications by our group [7-9].

It has been suggested that an approach could be to develop BCs based on Si-Cr-Fe alloys with oxidation resistant phases and limited oxygen penetration [10]. Silicides and Si-rich intermetallic alloys, such as the $\mathrm{R} 512$ coatings [11], can form $\mathrm{SiO}_{2}$ coatings with the potential to form a glass layer able to prevent oxidation, scale cracking, and spallation. $\mathrm{SiO}_{2}$ would also prevent the increase of the substrate surface temperature and can be self-healing [12]. However, even though complex Si-rich intermetallics were found to provide optimum protection against oxidation to conventional $\mathrm{Nb}$-rich alloys (i.e., not $\mathrm{Nb}$-silicide based alloys), poor mechanical behavior has been reported for coatings with high silicon contents that formed $\mathrm{SiO}_{2}$ protective scales [13,14].

Iron-modified silicide coatings have provided oxidation protection to conventional $\mathrm{Nb}$-rich alloys. This was attributed to the selective oxidation of silicon in coatings with $\mathrm{FeSi}, \mathrm{FeSi}_{2}, \mathrm{FeSi}_{2} \mathrm{Ti}_{\text {, and }} \mathrm{TM}_{7} \mathrm{Si}_{6}$ phases in their microstructure, where $\mathrm{TM}=\mathrm{Fe}, \mathrm{Ti}, \mathrm{Cr}, \mathrm{Nb}[10,15,16]$. Data about the oxidation of modified (alloyed) iron silicides is scarce. Additions of the above elements could alter the melting point of $\mathrm{Fe}$ silicides and affect their oxidation and mechanical performance at high temperatures. It is not known whether formation of protective oxides, such as $\mathrm{Cr}_{2} \mathrm{O}_{3}, \mathrm{SiO}_{2}$, and $\mathrm{Al}_{2} \mathrm{O}_{3}$, could be possible with $\mathrm{Al}$ addition to Fe-based silicide coatings.

Studies of the oxidation of Si-rich Fe-Si alloys at intermediate and high temperatures attributed a reduction in the oxidation rate to the formation of $\mathrm{SiO}_{2}$ [17]. Amorphous $\mathrm{SiO}_{2}$ has been the desirable oxidation product for these alloys because it has good adhesion to silicide phases, low oxygen diffusion, and ability to resist plastic deformation at high temperatures.

For $\mathrm{Nb}$-silicide base alloys, different coating systems have been considered to promote the formation of alumina or silica scales [18-20]. Different configurations of coating systems for turbine blades of $\mathrm{Nb}$-silicide based alloys have been proposed [21,22]. For example, the coating could consist of a diffusion barrier layer and inert bond coat, or in addition to these could also have a platinum group metal layer, a $\mathrm{Cr}_{2} \mathrm{Nb}$ Laves layer, and a chromium layer. These would form a bond coat, on top of which a ceramic top coat (thermal barrier) would be deposited.

One approach in the design of an environmentally resistant coating system for a $\mathrm{Nb}$-silicide based alloy is to use a layered multi-material or functionally gradient $\mathrm{BC}$ with decreased $\mathrm{Nb}$ content and increased capability to form $\mathrm{Si}$ and $\mathrm{Al}$ oxides from the $\mathrm{Nb}$-silicide-based substrate surface towards the top coat. The latter would be deposited on the top component of the BC (i.e., the one furthest away from the substrate) that could form in situ $\alpha \mathrm{Al}_{2} \mathrm{O}_{3}$ (preferred) or $\mathrm{SiO}_{2} \mathrm{TGO}$. Recently, our group reported on research seeking suitable $\mathrm{BC}$ alloys [7-9]. The motivation of the research reported in this paper was to find out the effect of $\mathrm{Al}$ addition on the microstructure and oxidation of silicide based coatings of the Si-Fe-Cr-Ti-Al-Nb system. In this paper we report on an alloy of this system.

The structure of the paper is as follows. First we discuss the selection of the composition of the alloy to be studied. Then, the experimental details are given followed by the results about the cast and heat treated microstructures and the isothermal oxidation of the alloy. In the discussion we first deliberate on the microstructure of the alloy and then on its oxidation. The alloy is compared with other alumina or silica scale-forming alloys and alloys are suggested for BCs. 


\section{Selection of Alloy Composition}

The alloying behavior of the key phases in $\mathrm{Nb}$-silicide based alloys can be described using the parameters $\delta$ (related to atomic size), $\Delta \chi$ (related to electronegativity), and the number of valence electrons per atom filled into the valence band (VEC) [23-25]. These three parameters are also key in the alloy design methodology NICE (Niobium Intermetallic Composite Elaboration) that has been developed for the design and selection of new $\mathrm{Nb}$-silicide-based alloys with a balance of mechanical and oxidation properties [3]. NICE was used to select the alloys MG5, MG6, and MG7 [7,8] (see below).

Recently, in maps of the parameters $\delta, \Delta x$, and VEC (Figure 23 in a previous study [9]), it was shown that two alloys with microstructures consisting of Si-rich transition metal silicides, namely the alloys $\mathrm{OHC} 1$ and $\mathrm{OHC} 5$ with nominal compositions (at.\%) Si-23Fe-15Cr-15Ti-1Nb (OHC1) and $\mathrm{Si}-25 \mathrm{Nb}-5 \mathrm{Al}-5 \mathrm{Cr}-5 \mathrm{Ti}$ (OHC5), correlated well with $\mathrm{Nb}$-Ti-Si-Al-Hf alloys with microstructures consisting of Si-rich transition metal silicides and transition metal aluminides, namely the alloys MG5, MG6, and MG7 of nominal compositions (at.\%) 14.5Nb-27Si-22.5Ti-32.5Al-3.5Hf (MG5), 13.5Nb-23Si-23Ti-37Al-3.5Hf (MG6), and 13Nb-24Si-24Ti-35Al-4Hf (MG7), respectively. The alloy OHC5 was "closer" to the latter three Al-rich alloys ( $32.5<\mathrm{Al}<37$ at.\%), and similar to them it formed alumina scale but at a significantly lower $\mathrm{Al}$ concentration (5 at.\%). The alloy $\mathrm{OHC1}$, with no $\mathrm{Al}$ addition, was "further away" and formed scales composed of silica, chromia, and titania oxides. In a previous study [9] it was suggested that the alloy $\mathrm{OHC} 1$ would not be suitable as a $\mathrm{BC}$ component for $\mathrm{Nb}$-silicide based components owing to the likelihood of melting above $1100^{\circ} \mathrm{C}$. Would the same be the case if $\mathrm{Al}$ were to be present in the alloy, or, to put it in another way, what would the effect of $\mathrm{Al}$ addition be on microstructure stability and oxidation behavior of an $\mathrm{OHC} 1$ type alloy?

To answer this question, we selected a silicide alloy based on the alloy $\mathrm{OHC} 1$ that was designed to have $\mathrm{Al}$ substituting $\mathrm{Cr}, \mathrm{Si}$, and $\mathrm{Ti}$, and its microstructure to include the same silicides as $\mathrm{OHC1}$, but (a) with the constraint the alloy to be located between the alloys OHC1 and OHC5 in the aforementioned maps and (b) with three requirements, namely the alloy (i) to have no stable $\mathrm{Nb}$ solid solution in its microstructure, (ii) to not pest, and (iii) to not form $\mathrm{Nb}$ oxides. Considering the phase equilibria for the ternary systems Cr-Si-Ti [26], Fe-Si-Ti [27], Cr-Fe-Si [28], Cr-Nb-Si [29] and Al-Fe-Si [30], the composition of the alloy OHC1 [9] and (a) and (b), the Si and Al concentrations, respectively, of 40 and 12 at. $\%$ were selected to penetrate the alloy microstructures consisting of $\mathrm{TM}_{6} \mathrm{Si}_{5}$ ( $\mathrm{TM}=$ transition metal), $\mathrm{TM}_{5} \mathrm{Si}_{3}, \mathrm{~B} 20$, and $\mathrm{C} 40$ compounds. The $\mathrm{Al}$ addition was expected to promote the formation of the $\mathrm{Fe}_{3} \mathrm{Al}_{2} \mathrm{Si}_{3}$ phase. The reasons for the choice of above phases were discussed in a previous study [9].

The nominal composition (at.\%) of the alloy was Si-22Fe-12Cr-12Al-10Ti-5Nb (OHC2). The Figure 1a,b shows the alloys $\mathrm{OHC1}, \mathrm{OHC} 2$, and $\mathrm{OHC} 5$, and MG5, MG6, and MG7 [7,8] without the data for Zone A of the alloy MG7 [7], which is included in the Figure 1c,d. The correlations are good. When the data for Zone A was included, the $\mathrm{R}^{2}$ values decreased in the $\delta$ versus VEC map (Figure 1d) and $\Delta \chi$ versus VEC map (not shown, $R^{2}=0.5504$ ) and increased in the $\Delta \chi$ versus $\delta$ map from $R^{2}=0.7153$ (map not shown) to $R^{2}=0.85$ (Figure 1c).

As was the case in previous studies [7-9], the alloy was not studied as a coating applied on a $\mathrm{Nb}$-silicide-based substrate in order to eliminate the effects of substrate and coating process on microstructure and oxidation. 

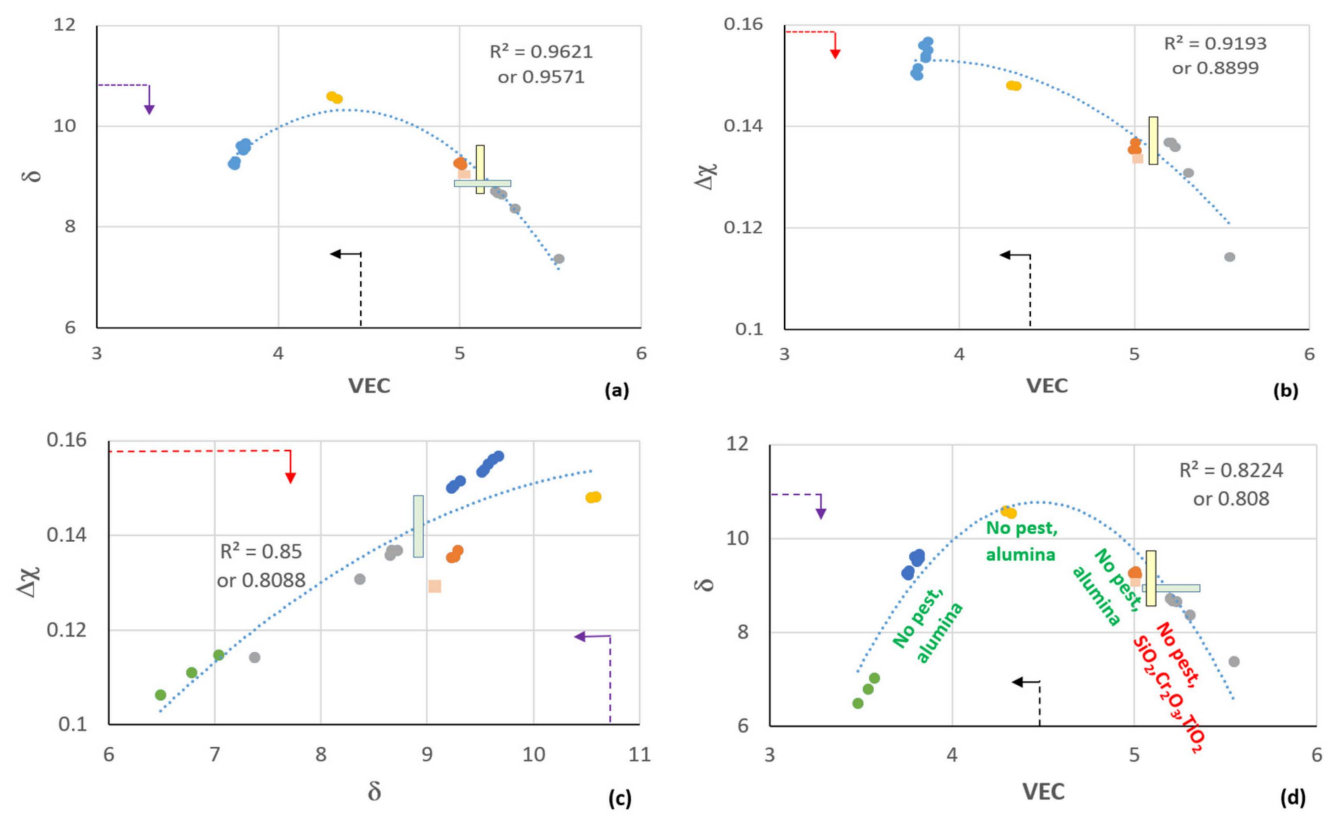

Figure 1. Maps of the parameters $\delta, \Delta x$, and VEC for the alloys OHC2 (orange), OHC1 (grey), OHC5 (gold), MG5, MG6, MG7 (blue), and Zone A in alloy MG7 (green): (a) $\delta$ versus VEC, (b) $\Delta x$ versus VEC, (c) $\Delta x$ versus $\delta,($ d) $\delta$ versus VEC. Data points for Zone A in OHC2 are shown by squares. For the yellow and green boxes and dashed lines and arrows, see text. (a-d) The lower $R^{2}$ value is for data that includes Zone A of the alloy OHC2.

\section{Experimental}

We used arc melting with a non-consumable tungsten electrode and a water-cooled copper crucible, a voltage of $50 \mathrm{~V}$, and a current of $650 \mathrm{~A}$ to prepare the alloy from pure elements ( $\geq 99.9 \mathrm{wt} . \%$ purity) in a Ti-gettered Ar atmosphere. The button was melted 5 times to homogenize its composition. For the heat treatments we used an alumina tube furnace and a Ti-gettered Ar atmosphere. The specimens were polished, wrapped in Ta foil to minimize contamination by oxygen, and were placed in an alumina crucible.

The microstructures were characterized using Scanning Electron Microscopy (SEM) and X-ray diffraction (XRD). Philips PSEM 500 SEM (Philips-ThermoFisher Scientific, Hillsboro, OR, USA), Jeol JSM 6400 SEM (Jeol, Tokyo, Japan), and Inspect F FEG SEM microscopes (ThermoFisher Scientific, Hillsboro, OR, USA) were used. The back scatter electron (BSE) mode was used to study the microstructures with qualitative and quantitative EDS analysis (Oxford Instruments, Abington, UK) of the alloy and phases $(20 \mathrm{kV}$ for EDS quantitative analysis and $20 \mathrm{kV}$ and $15 \mathrm{kV}$, respectively, for the X-ray elemental maps of the scale surface and cross sections of oxidized specimens). EDS standardization was performed using specimens of high purity $\mathrm{Nb}, \mathrm{Ti}, \mathrm{Cr}, \mathrm{Fe}, \mathrm{Si}, \mathrm{Al}$, and $\mathrm{Co}$ standards that were polished to $1 \mu \mathrm{m}$ finish. The EDS was calibrated prior to analysis with the Co standard. At least five large area analyses were performed in the top, bulk, and bottom of the button, and at least ten analyses were obtained from each phase with size $\geq 5 \mu \mathrm{m}$ to determine actual compositions.

A Siemens D500 XRD diffractometer (XRD, Hiltonbrooks Ltd, Crew, UK) with CuK $\alpha$ radiation $(\lambda=1.540562 \AA), 2 \theta$ from $20^{\circ}-120^{\circ}$, and a step size of $0.02^{\circ}$ was used. For glancing angle XRD (GXRD), a Siemens D5000 diffractometer with $\mathrm{Cu} \mathrm{K} \alpha 1$ and $\mathrm{K} \alpha 2$ radiation $\left(\lambda=1.54178 \AA\right.$ ), $2 \theta$ from $10^{\circ}-100^{\circ}$, and a step size of $0.02^{\circ}$ was used. Peaks in the XRD diffractograms were identified by correlating data from the experiments with that from the JCPDS data (International Centre for Diffraction Data). The scan type used for GXRD was a detector scan, while for regular specimens it was a locked coupled scan. Prior to GXRD experiments the glancing angle was selected with the aid of the AbsorbDX software (Bruker, Karlsruhe, Germany), which evaluates the X-ray penetration depth for particular glancing angle conditions. 
The isothermal oxidation was studied at $800^{\circ} \mathrm{C}$ for $100 \mathrm{~h}$ in laboratory air using thermo-gravimetric analysis (TGA) in a Netzsch STA F3 TG/DSC analyzer (Netzsch Gmbh, Waldkraiburg, Germany) with a $\mathrm{SiC}$ furnace and alumina crucible specimen holder with air flow rate of $20 \mathrm{~mL} / \mathrm{min}$ and with heating and cooling rates of $3{ }^{\circ} \mathrm{C} / \mathrm{min}$. Cubic specimens of size $3 \mathrm{~mm} \times 3 \mathrm{~mm} \times 3 \mathrm{~mm}$ were used for the TGA experiments. The specimens were cut from the as-cast alloy and polished to 800 grit $\mathrm{SiC}$ finish. For the DSC experiments a Rh/Pt furnace was used in the Netzsch STA F3 TG/DSC analyzer with an Ar flow rate of $20 \mathrm{~mL} / \mathrm{min}$. The specimens for thermal analysis and isothermal oxidation were selected from the bulk of the cast button.

\section{Results}

\subsection{Cast Alloy}

The actual composition (at.\%) of the cast alloy (OHC2-AC) was Si-21.5Fe-13.7Al-11.2Cr-8.5Ti-4.9Nb. This was the average composition of the large area analyses from all parts of the button. There was macrosegregation of all the elements. The bottom of the button was leaner in $\mathrm{Nb}, \mathrm{Ti}, \mathrm{Cr}$, and $\mathrm{Si}$ and richer in Fe and $\mathrm{Al}$ compared with its other parts. Near the copper crucible wall a zone was formed (Figure 2a,b) with average composition Si-27.9Fe-25.5Al-7.1Cr-3Ti-1.1Nb. We shall refer to this as Zone A [7]. The microstructures are shown in Figure 2c-h.

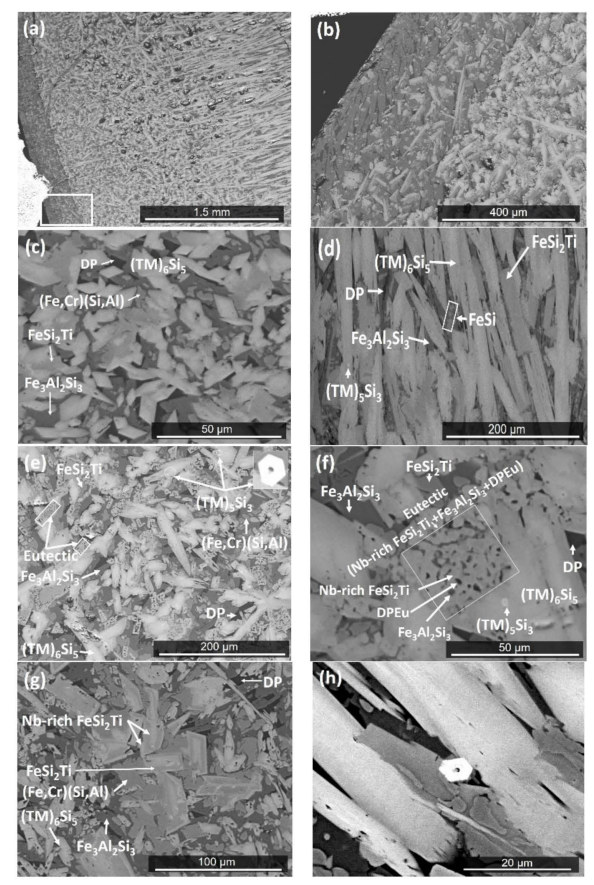

Figure 2. BSE images of OHC2-AC: (a) Zone A formed near water cooled copper crucible $(\times 40)$, (b) microstructure of area indicated by insert in (a), (c) top, (d) bulk, (e) near bottom, (f) near bottom showing eutectic, (g) Zone A, and (h) bulk showing hexagonal grains of $\mathrm{TM}_{5} \mathrm{Si}_{3}$.

The EDS (Table 1) and XRD (Figure 3) data confirmed that the microstructure consisted of six phases, namely the $\mathrm{TM}_{6} \mathrm{Si}_{5}$ silicide with light graded contrast, the $\mathrm{TM}_{5} \mathrm{Si}_{3}$ silicide that exhibited white contrast (see Figure $2 \mathrm{~d}, \mathrm{~h})(\mathrm{TM}=\mathrm{Nb}, \mathrm{Ti}, \mathrm{Fe}, \mathrm{Cr})$, the phases $\tau_{1}=\mathrm{FeSi}_{2} \mathrm{Ti}$ and $(\mathrm{Fe}, \mathrm{Cr})(\mathrm{Si}, \mathrm{Al})$ with similar grey contrast but different morphology, the $\mathrm{Fe}_{3} \mathrm{Al}_{2} \mathrm{Si}_{3}$ phase with the dark grey contrast, and the dark phase (DP) with dark contrast in Figure 2. The average compositions of these phases are given in Table 1 . The $(\mathrm{Fe}, \mathrm{Cr})(\mathrm{Si}, \mathrm{Al}), \mathrm{Fe}_{3} \mathrm{Al}_{2} \mathrm{Si}_{3}$, and dark phase (DP) essentially were $\mathrm{Nb}$ - and Ti-free. 
Table 1. EDS data* (at.\%) of the phases in the cast alloy OHC2.

\begin{tabular}{ccccccc}
\hline Phase & Nb (at.\%) & Ti (at.\%) & Cr (at.\%) & Fe (at.\%) & Al (at.\%) & Si (at.\%) \\
\hline \multirow{2}{*}{$(\mathrm{TM})_{5} \mathrm{Si}_{3}$} & $16.2 \pm 1.1$ & $21.4 \pm 1.2$ & $16.1 \pm 0.7$ & $6.7 \pm 0.9$ & $1.8 \pm 0.7$ & $37.7 \pm 1.0$ \\
& $17.9-14.3$ & $22.9-18.9$ & $17.3-15.0$ & $8.3-5.4$ & $3.3-1.1$ & $40.0-36.8$ \\
\hline $\mathrm{TM}_{6} \mathrm{Si}_{5}$ & $7.9 \pm 2.0$ & $12.4 \pm 0.8$ & $18.5 \pm 0.8$ & $14.5 \pm 2.8$ & $2.0 \pm 0.4$ & $44.8 \pm 0.4$ \\
& $11.2-4.1$ & $13.8-10.9$ & $20.0-17.0$ & $20.0-10.2$ & $2.8-1.3$ & $46.4-44.1$ \\
\hline $\mathrm{FeSi}_{2} \mathrm{Ti}$ & $4.3 \pm 0.6$ & $14.6 \pm 0.8$ & $5.7 \pm 0.3$ & $23.3 \pm 0.4$ & $12.5 \pm 1.0$ & $39.6 \pm 0.6$ \\
& $5.2-3.1$ & $15.9-13.1$ & $6.3-5.3$ & $23.8-22.7$ & $13.8-10.4$ & $40.9-38.6$ \\
\hline \multirow{2}{*}{$(\mathrm{Fe}, \mathrm{Cr})(\mathrm{Si}, \mathrm{Al})$} & 0.1 & 0.4 & $9.2 \pm 0.8$ & $37.1 \pm 0.7$ & $8.5 \pm 0.6$ & $44.7 \pm 0.4$ \\
& - & - & $10.4-7.2$ & $38.8-36.0$ & $10.2-7.4$ & $45.4-43.7$ \\
\hline \multirow{2}{*}{$\mathrm{Fe}_{3} \mathrm{Al}_{2} \mathrm{Si}{ }_{3}$} & 0.1 & 0.3 & $4.6 \pm 0.4$ & $30.2 \pm 0.6$ & $32.2 \pm 0.8$ & $32.6 \pm 0.6$ \\
& - & - & $5.4-3.7$ & $31.1-28.6$ & $34.2-30.7$ & $34.4-31.5$ \\
\hline \multirow{2}{*}{ Dark phase $(\mathrm{DP})$} & 0.1 & 0.3 & $3.5 \pm 0.3$ & $21.3 \pm 0.5$ & $57.5 \pm 1.7$ & $17.3 \pm 1.2$ \\
& - & - & $4.3-2.9$ & $22.7-20.6$ & $59.3-54.0$ & $19.5-16.0$ \\
\hline Eutectic & $5.5 \pm 0.6$ & $11.8 \pm 0.7$ & $5.0 \pm 0.6$ & $22.5 \pm 0.7$ & $16.0 \pm 2.2$ & $39.3 \pm 1.0$ \\
$($ large area analysis) & $6.3-4.2$ & $12.9-10.6$ & $6.1-4.4$ & $23.4-21.6$ & $20.8-12.6$ & $40.9-37.0$ \\
\hline FeSi $2 \mathrm{Ti}$ & $7.1 \pm 0.8$ & $14.4 \pm 0.4$ & $5.2 \pm 0.7$ & $21.9 \pm 0.6$ & $9.7 \pm 0.8$ & $41.7 \pm 0.6$ \\
(in eutectic) & $8.5-5.8$ & $15.5-14.0$ & $7.6-4.2$ & $23.0-21.0$ & $11.6-8.5$ & $42.5-40.0$ \\
\hline Fe ${ }_{3} \mathrm{Al}_{2} \mathrm{Si}{ }_{3}$ & 0.9 & $2.4 \pm 1.9$ & $4.5 \pm 0.4$ & $28.5 \pm 1.4$ & $29.2 \pm 2.1$ & $34.5 \pm 0.7$ \\
(in eutectic) & - & $5.7-0.6$ & $5.3-4.0$ & $30.1-25.6$ & $31.6-26.4$ & $35.4-33.7$ \\
\hline (DPEu) & $2.5 \pm 0.6$ & $5.8 \pm 1.0$ & $3.9 \pm 0.3$ & $20.7 \pm 0.3$ & $39.8 \pm 3.9$ & $27.3 \pm 2.4$ \\
& $3.4-1.7$ & $7.4-4.6$ & $4.3-3.5$ & $21.1-20.3$ & $45.3-35.2$ & $30.3-23.9$ \\
\hline
\end{tabular}

Note: * data includes the average value, standard deviation, and the maximum and minimum analysis values.

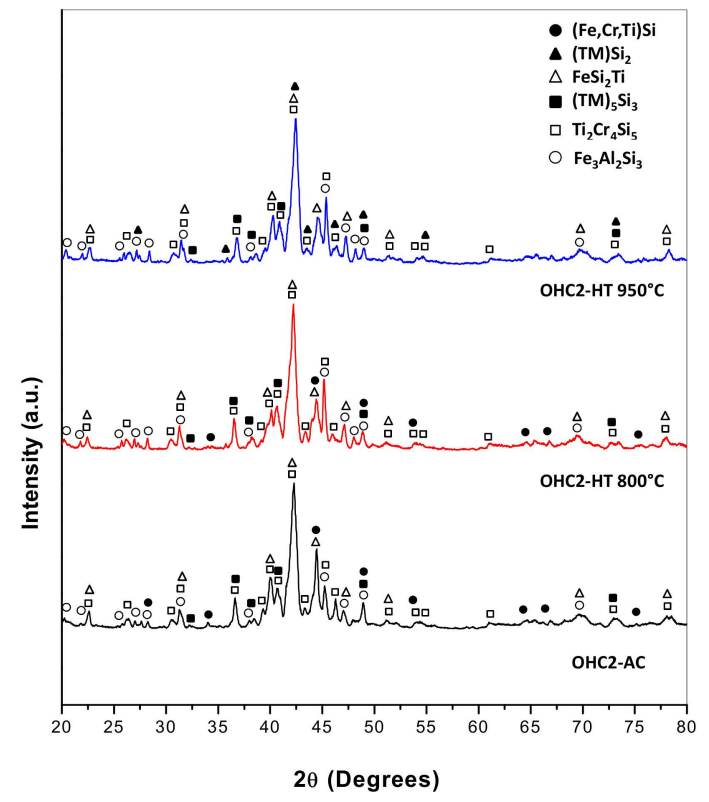

Figure 3. X-ray diffractograms of the cast and heat treated alloy $\mathrm{OHC2.}$

The $\mathrm{TM}_{6} \mathrm{Si}_{5}$ silicide was orthorhombic with the $\mathrm{V}_{6} \mathrm{Si}_{5}$ as prototype and Ibam space group (JCPDS card 54-381). The $\mathrm{TM}_{5} \mathrm{Si}_{3}$ silicide was based on the $\mathrm{Ti}_{5} \mathrm{Si}_{3}$ hexagonal silicide with the $\mathrm{P}_{3} / \mathrm{mcm}$ space group (JCPDS card 89-3721). The $\mathrm{FeSi}_{2} \mathrm{Ti}$ phase had the $\mathrm{MnSi}_{2} \mathrm{Ti}$ prototype with the Pbam space group (JCPDS card 75-2180). Its composition matched with the composition of the $\tau_{1}$ phase in [31]. The $(\mathrm{Fe}, \mathrm{Cr})(\mathrm{Si}, \mathrm{Al})$ had the B20 structure with the P2 ${ }_{1} 3$ space group (JCPDS card 38-1397). The $\mathrm{Fe}_{3} \mathrm{Al}_{2} \mathrm{Si}_{3}$ phase was triclinic with the P-1 space group (JCPDS card 87-1920). 
The microstructure in the top of the button is shown in Figure 2c. The $\mathrm{TM}_{6} \mathrm{Si}_{5}$ silicide had a facetted morphology and microsegregation. The $\mathrm{FeSi}_{2} \mathrm{Ti}$ had an irregular shape and was mainly formed at the grain boundaries of the $\mathrm{TM}_{6} \mathrm{Si}_{5}$, while the $\mathrm{Fe}_{3} \mathrm{Al}_{2} \mathrm{Si}_{3}$ exhibited facetted plate like morphology. Small hexagonal grains of the $\mathrm{TM}_{5} \mathrm{Si}_{3}$ silicide of bright contrast were randomly distributed and formed at a low volume fraction only in those areas of the top that were close to the bulk. The volume fraction of the dark phase (DP) also was very low.

In the bulk of the button, the microstructure comprised of a large volume fraction of facetted $\mathrm{TM}_{6} \mathrm{Si}_{5}$. There was microsegregation in this phase that resulted in graded BSE contrasts (Figure 2d), showing a light contrast in the center and dark grey contrast in the edges. The center of $\mathrm{TM}_{6} \mathrm{Si}_{5}$ was richer in $\mathrm{Nb}, \mathrm{Ti}, \mathrm{Si}$, and $\mathrm{Cr}$, and the edges were rich in $\mathrm{Fe}$ and $\mathrm{Al}$ (Figure 4). For example, in one $\mathrm{TM}_{6} \mathrm{Si}_{5}$ grain the concentrations (at.\%) of these elements were about $11.2 \mathrm{Nb}, 10.9 \mathrm{Fe}, 18.8 \mathrm{Cr}, 12.4 \mathrm{Ti}$, $44.8 \mathrm{Si}$, and $1.9 \mathrm{Al}$ in the bulk, and $5.2 \mathrm{Nb}, 21.9 \mathrm{Fe}, 14.1 \mathrm{Cr}, 11.4 \mathrm{Ti}, 42.7 \mathrm{Si}$, and $4.7 \mathrm{Al}$ at the edge of the grain. Similar variations in composition were observed in other $\mathrm{TM}_{6} \mathrm{Si}_{5}$ grains. In general, the change of the concentrations of $\mathrm{Cr}, \mathrm{Si}$, and Ti from the bulk to the edge of $\mathrm{TM}_{6} \mathrm{Si}_{5}$ grains was not as striking as for $\mathrm{Fe}$ and $\mathrm{Nb}$ (Figure 4). The $\mathrm{FeSi}_{2} \mathrm{Ti}$ and $(\mathrm{Fe}, \mathrm{Cr})(\mathrm{Si}, \mathrm{Al})$ phases had similar grey contrast and different morphology. The $\mathrm{FeSi}_{2} \mathrm{Ti}$ was facetted (like rectangles) and formed on the grain boundaries of the $\mathrm{TM}_{6} \mathrm{Si}_{5}$. The $(\mathrm{Fe}, \mathrm{Cr})(\mathrm{Si}, \mathrm{Al})$ was mostly found as isolated particles in the vicinity of $\mathrm{FeSi}_{2} \mathrm{Ti}_{\text {. }}$ The $\mathrm{Fe}_{3} \mathrm{Al}_{2} \mathrm{Si}_{3}$ was cracked. The dark phase (DP) was mainly found between the $\mathrm{TM}_{6} \mathrm{Si}_{5}$ and the $\mathrm{Fe}_{3} \mathrm{Al}_{2} \mathrm{Si}_{3}$, was formed at a low volume fraction, and its $\mathrm{Si}$ and $\mathrm{Al}$ concentrations varied significantly. The contrast of the small hexagonal grains of $\mathrm{TM}_{5} \mathrm{Si}_{3}$ was darker in the bulk and the silicide was distributed unevenly.

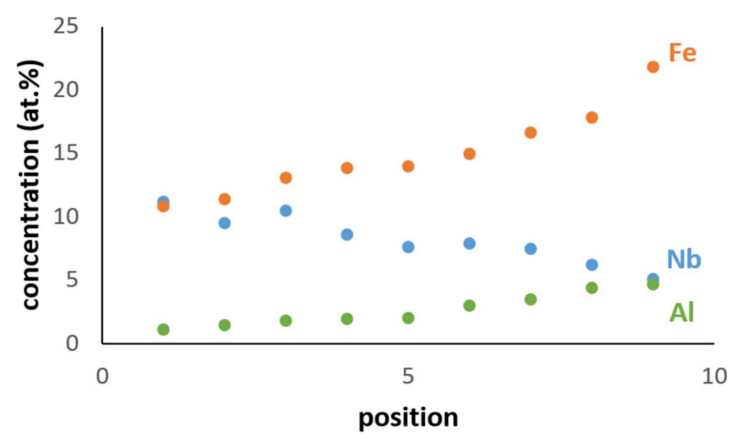

Figure 4. $\mathrm{Al}, \mathrm{Fe}$, and $\mathrm{Nb}$ concentrations from near the bulk (center) of one $\mathrm{TM}_{6} \mathrm{Si}_{5}$ grain to near its edge. Center and edge correspond to positions zero and ten, respectively.

Near the bottom of the button (Figure 2e), the volume fraction of the $\mathrm{TM}_{6} \mathrm{Si}_{5}$ was reduced. The $\mathrm{TM}_{5} \mathrm{Si}_{3}, \mathrm{Fe}_{3} \mathrm{Al}_{2} \mathrm{Si}_{3}$, and DP phases were present with the same features as in the bulk of the button. In this area the $\mathrm{TM}_{6} \mathrm{Si}_{5}$ had more voids and cracks. A ternary eutectic was formed. This eutectic consisted of the $\mathrm{FeSi}_{2} \mathrm{Ti}$ phase (light contrast), the $\mathrm{Fe}_{3} \mathrm{Al}_{2} \mathrm{Si}_{3}$ phase with dark grey contrast and a dark contrast phase (labelled DPEu in the Figure 2f), with average compositions given in Table 1 . The $(\mathrm{Fe}, \mathrm{Cr})(\mathrm{Si}, \mathrm{Al})$ was in the form of isolated particles embedded in the $\mathrm{Fe}_{3} \mathrm{Al}_{2} \mathrm{Si}_{3}$ phase. The EDS data for $\mathrm{Fe}_{3} \mathrm{Al}_{2} \mathrm{Si}_{3}$ and DPEu could be not very accurate because very small areas were analyzed. However, it was clear that the phase with the dark grey contrast was the $\mathrm{Fe}_{3} \mathrm{Al}_{2} \mathrm{Si}_{3}$.

In Zone A the volume fraction of the dark phase (DP) was slightly higher than in the rest of the button (Figure $2 \mathrm{~g}$ ). The $\mathrm{TM}_{6} \mathrm{Si}_{5}, \mathrm{FeSi}_{2} \mathrm{Ti}$, and $(\mathrm{Fe}, \mathrm{Cr})(\mathrm{Si}, \mathrm{Al})$ phases were present at lower volume fraction and the volume fraction of the $\mathrm{Fe}_{3} \mathrm{Al}_{2} \mathrm{Si}_{3}$ was the same as in the rest of the button. The $\mathrm{FeSi}_{2} \mathrm{Ti}$ was facetted (like trapezoids) and exhibited microsegregation; its brighter and darker contrast areas, respectively, were $\mathrm{Nb}$-rich and $\mathrm{Nb}$-poor. The $(\mathrm{Fe}, \mathrm{Cr})(\mathrm{Si}, \mathrm{Al})$ surrounded these facetted grains (Figure $2 \mathrm{~g}$ ). The Fe-rich $\mathrm{TM}_{6} \mathrm{Si}_{5}$ was either facetted or had irregular shape. The $\mathrm{TM}_{5} \mathrm{Si}_{3}$ and eutectic were not observed in the Zone A. 
In the DSC trace (Figure 5) there was a small endothermic peak at about $973{ }^{\circ} \mathrm{C}$, with a corresponding strong peak on cooling. Krendelsberger et al. [32] gave $975^{\circ} \mathrm{C}$ as the melting temperature of $\mathrm{Fe}_{3} \mathrm{Al}_{2} \mathrm{Si}_{3}$. The second peak on heating was very strong and could correspond to an invariant reaction. This peak could be related to the ternary eutectic $\mathrm{L} \rightarrow \mathrm{FeSi}_{2} \mathrm{Ti}+\mathrm{Fe}_{3} \mathrm{Al}_{2} \mathrm{Si}_{3}+\mathrm{DPEu}$. There was also a broad endothermic peak at about $1125^{\circ} \mathrm{C}$ but with no corresponding peak on cooling. The microstructure of the alloy was studied after heat treatments at 800,950 , and $1200{ }^{\circ} \mathrm{C}$ for $48 \mathrm{~h}$.

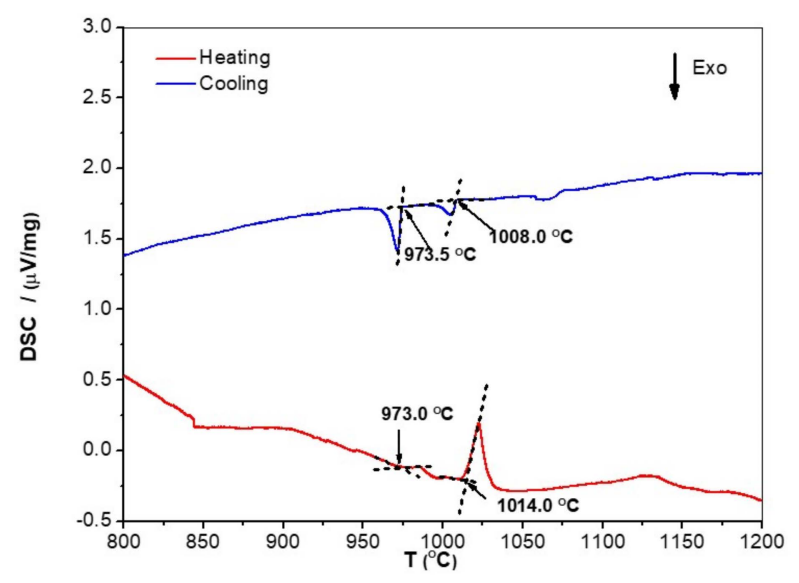

Figure 5. DSC trace of the alloy OHC2.

\subsection{Heat Treated Alloy}

The actual composition after the heat treatment at $800{ }^{\circ} \mathrm{C}(\mathrm{OHC} 2-\mathrm{HTA})$ was $\mathrm{Si}-21.5 \mathrm{Fe}-11.4 \mathrm{Cr}-$ 12.9Al-8.6Ti-5Nb, essentially the same as the cast alloy. Chemical inhomogeneity and Zone A were still present. The latter was richer in $\mathrm{Al}$ compared with $\mathrm{OHC}-\mathrm{AC}(\mathrm{Si}-27.1 \mathrm{Fe}-29.3 \mathrm{Al}-6.6 \mathrm{Cr}-2.3 \mathrm{Ti}-0.8 \mathrm{Nb})$. According to the XRD (Figure 3) and EDS data, the microstructure consisted of the same six phases, namely the $\mathrm{TM}_{6} \mathrm{Si}_{5}, \mathrm{TM}_{5} \mathrm{Si}_{3}, \mathrm{FeSi}_{2} \mathrm{Ti},(\mathrm{Fe}, \mathrm{Cr})(\mathrm{Si}, \mathrm{Al}), \mathrm{Fe}_{3} \mathrm{Al}_{2} \mathrm{Si}_{3}$, and the dark phase (DP). The compositions of the phases essentially were the same as in the cast alloy, with the exception of the dark phase (DP), which was richer in $\mathrm{Al}$ and poorer in $\mathrm{Si}$ (3.5(0.7) Cr-22.6(0.8) $\mathrm{Fe}-59.1(2.3) \mathrm{Al}-14.3(1.4) \mathrm{Si}-0.5 \mathrm{Ti}-0.1 \mathrm{Nb}$, in parentheses are given the standard deviations). The typical microstructures of OHC2-HTA are shown in Figure 6a,b.

It can be seen that the microstructure had become coarser. There was some homogenization of the $\mathrm{TM}_{6} \mathrm{Si}_{5}$ silicide, the $\mathrm{FeSi}_{2} \mathrm{Ti}$ appeared to be more facetted, and although it was mainly found in the boundaries of the $\mathrm{TM}_{6} \mathrm{Si}_{5}$, it was also found as isolated plates. The volume fraction of $\mathrm{Fe}_{3} \mathrm{Al}_{2} \mathrm{Si}_{3}$ had increased. The dark phase (DP) was not found in the top and bulk of the button but was still present near the bottom, where the retained prior ternary eutectic was observed (Figure $6 b$ ) with average composition essentially the same as in the cast alloy. In Zone A, the volume fraction of $\mathrm{TM}_{6} \mathrm{Si}_{5}$ was reduced and its chemical inhomogeneity was still present. Tiny hexagonal particles of the $\mathrm{TM}_{5} \mathrm{Si}_{3}$ with very bright contrast, $\mathrm{Fe}_{3} \mathrm{Al}_{2} \mathrm{Si}_{3}$ plates, and the dark phase (DP) were observed.

The actual composition after the heat treatment at $950{ }^{\circ} \mathrm{C}(\mathrm{OHC} 2-\mathrm{HTB})$ was $\mathrm{Si}-21.5 \mathrm{Fe}-11.5 \mathrm{Cr}-$ 13Al-9.9Ti-4.3Nb, essentially the same as the cast alloy. The typical microstructure in the bulk of OHC2-HTB is shown in Figure 6c. According to the XRD (Figure 3) and EDS data, the microstructure consisted of the $\mathrm{TM}_{6} \mathrm{Si}_{5}, \mathrm{FeSi}_{2} \mathrm{Ti}_{2} \mathrm{Fe}_{3} \mathrm{Al}_{2} \mathrm{Si}_{3}, \mathrm{TM}_{5} \mathrm{Si}_{3}$, and $\mathrm{TMSi}_{2}$ phases. The $(\mathrm{Fe}, \mathrm{Cr})(\mathrm{Si}, \mathrm{Al})$ and dark phase (DP) were not present and the Cr-rich $\mathrm{TMSi}_{2}$ silicide was the new compound formed at this temperature. The chemical compositions of $\mathrm{TM}_{5} \mathrm{Si}_{3}$ and $\mathrm{Fe}_{3} \mathrm{Al}_{2} \mathrm{Si}_{3}$ essentially were the same as in the cast alloy, the $\mathrm{TM}_{6} \mathrm{Si}_{5}$ was richer in Ti and poorer in Fe (8.2Nb-14.7Ti-19.1Cr-11.9Fe-1.7Al-44.4Si), the $\mathrm{FeSi}_{2} \mathrm{Ti}$ was richer in $\mathrm{Ti}$ and poorer in $\mathrm{Al}(4.3 \mathrm{Nb}-17 \mathrm{Ti}-4.6 \mathrm{Cr}-23.1 \mathrm{Fe}-10.5 \mathrm{Al}-40.5 \mathrm{Si})$ and the average composition of $\mathrm{TMSi}_{2}$ was $1.1 \mathrm{Nb}-2.9 \mathrm{Ti}-22.9 \mathrm{Cr}-7.4 \mathrm{Fe}-18.6 \mathrm{Al}-47.1 \mathrm{Si}$. 


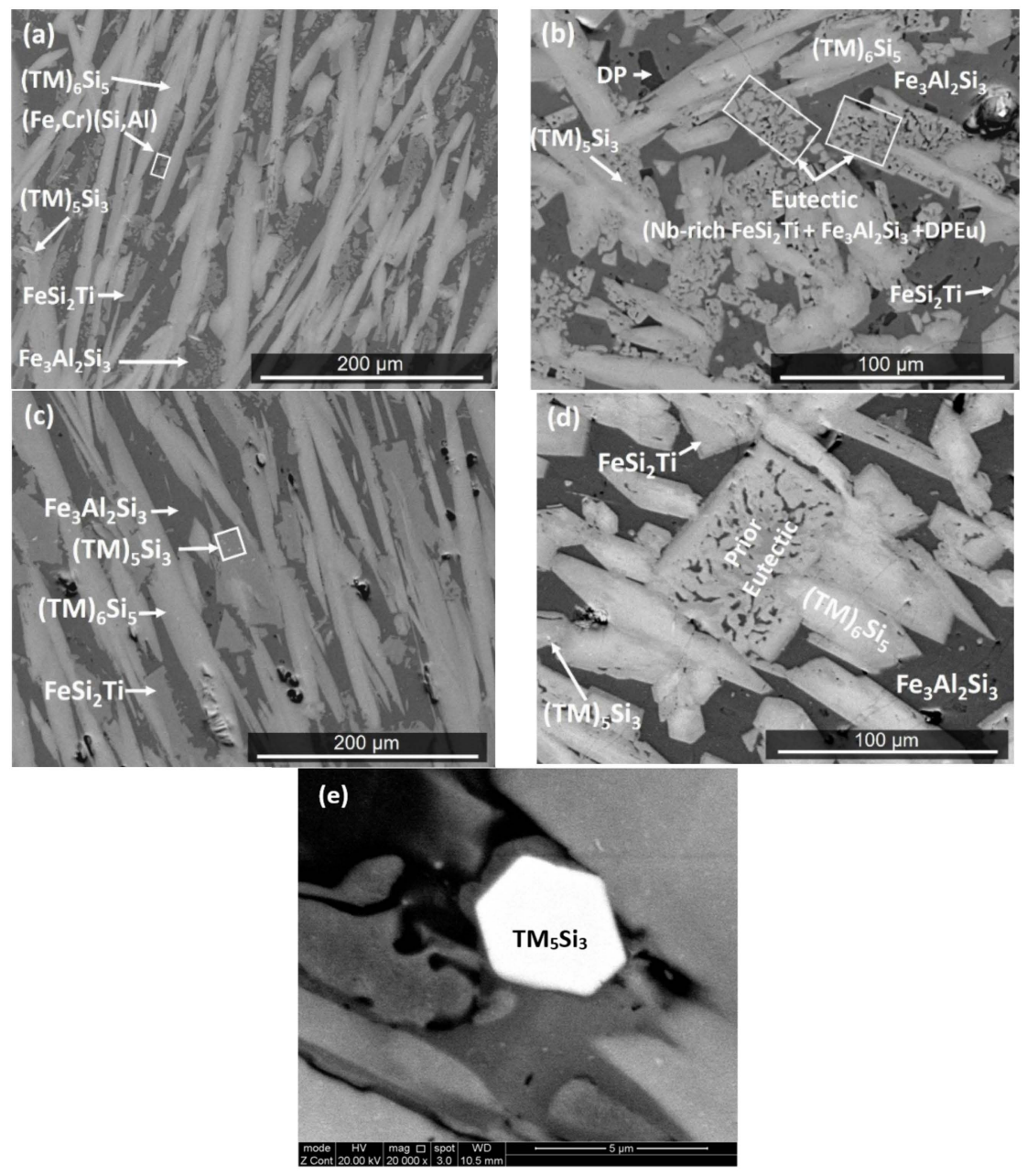

Figure 6. BSE images of the microstructures of the heat treated alloy, (a,b) OHC2-HTA, (c,d) OHC2-HTB, and (e) high magnification image of hexagonal $\mathrm{TM}_{5} \mathrm{Si}_{3}$ particles in (d).

The microstructures in the top and bulk were similar (Figure 6c). The $\mathrm{FeSi}_{2} \mathrm{Ti}$ had become coarser, was observed at the grain boundaries of $\mathrm{TM}_{6} \mathrm{Si}_{5}$, and sometimes linked $\mathrm{TM}_{6} \mathrm{Si}_{5}$ grains. Tiny hexagonal particles of $\mathrm{TM}_{5} \mathrm{Si}_{3}$ with very bright contrast were present. Near the bottom the areas of prior eutectic consisted of two phases, namely the $\mathrm{Nb}$-rich $\mathrm{FeSi}_{2} \mathrm{Ti}$ and $\mathrm{Fe}_{3} \mathrm{Al}_{2} \mathrm{Si}_{3}$ phases. The DPEu was absent (Figure 6d). These prior eutectic areas were now richer in Ti and poorer in $\mathrm{Al}(5.9 \mathrm{Nb}-13.8 \mathrm{Ti}-5.6 \mathrm{Cr}-21.9 \mathrm{Fe}-12.4 \mathrm{Al}-40.3 \mathrm{Si})$, with $\mathrm{Si}+\mathrm{Al}=52.7$ at. $\%$ compared with 55.2 at.\% in $\mathrm{OHC} 2-\mathrm{AC}$. In the bottom of the button the same microstructure was observed, plus the $\mathrm{TMSi}_{2}$ silicide.

When the alloy was heat treated at $1200^{\circ} \mathrm{C}$ the specimen had "collapsed", owing to liquation. The microstructure was similar to that of the cast alloy.

\subsection{Oxidation}

We used the equation $\ln (\Delta w)=\ln K+n \ln t$ for the analysis of the TGA data. In this equation $\Delta w=\frac{\Delta m}{A}$, where $\Delta w$ is the weight change per unit area, $\Delta m$ is the weight change, and $A$ is the surface area before exposure, and $\mathrm{K}$ and $t$ respectively are the reaction rate constant and the exposure time. For the linear, parabolic, and sub-parabolic or cubic oxidation kinetics, the values of $\mathrm{n}$ are 1, 0.5, and $\leq 0.3$, respectively. When there was more than one mechanism involved, the corresponding section in the TGA data was used to determine the oxidation kinetics using the equations $\Delta w=k_{l} \cdot t$ for linear oxidation and $(\Delta w)^{2}=k_{p} \cdot t$ for parabolic oxidation, where $\mathrm{k}_{1}$ and $\mathrm{k}_{\mathrm{p}}$, respectively, are the linear and parabolic rate constants [33]. 
The TGA data for the isothermal oxidation in air at $800{ }^{\circ} \mathrm{C}$ for $100 \mathrm{~h}$ is shown in the Figure 7. The alloy did not pest and gained weight per unit area of $0.27 \mathrm{mg} / \mathrm{cm}^{2}$. Its $\mathrm{n}$ value was 0.14 and its oxidation behavior was sub-parabolic. There was a very short initial period $(1 \mathrm{~h})$ of oxidation, in which the alloy gained weight with linear kinetics $\left(\mathrm{k}_{\mathrm{l}}=1.03 \times 10^{-7} \mathrm{~g} / \mathrm{cm}^{2} \mathrm{~s}\right)$, followed by a long period $(99 \mathrm{~h})$ of parabolic oxidation with $\mathrm{k}_{\mathrm{p}}=1 \times 10^{-13} \mathrm{~g}^{2} / \mathrm{cm}^{4} \mathrm{~s}$. The cubic specimen had retained its shape and had well-defined edges; it had a black color with some blue and reddish tones. The scale remained attached and there was no evidence of scale spallation.

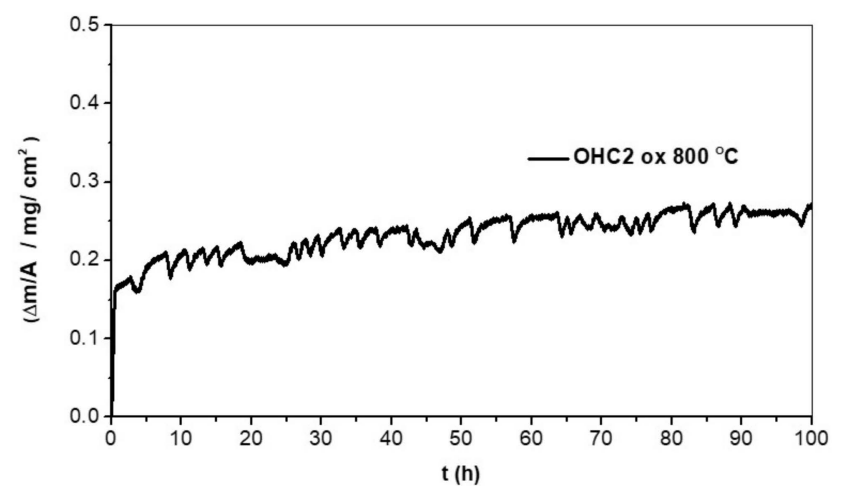

Figure 7. TGA data for isothermal oxidation in air at $800{ }^{\circ} \mathrm{C}$ for $100 \mathrm{~h}$.

Figure 8a shows the morphology of the surface of the scale. A continuous and adherent bright oxide with darker contrast was formed over the Fe-rich areas of $\mathrm{TM}_{6} \mathrm{Si}_{5}$ grains (Figure $8 \mathrm{~b}$ ). Similar characteristics were observed for the oxide formed over the $\mathrm{FeSi}_{2} \mathrm{Ti}_{\mathrm{i}}$ phase. Blade-like whiskers grew over the $\mathrm{Fe}_{3} \mathrm{Al}_{2} \mathrm{Si}_{3}$ (Figure 8a). The thickness of the scale varied between 1 and $2 \mu \mathrm{m}$.

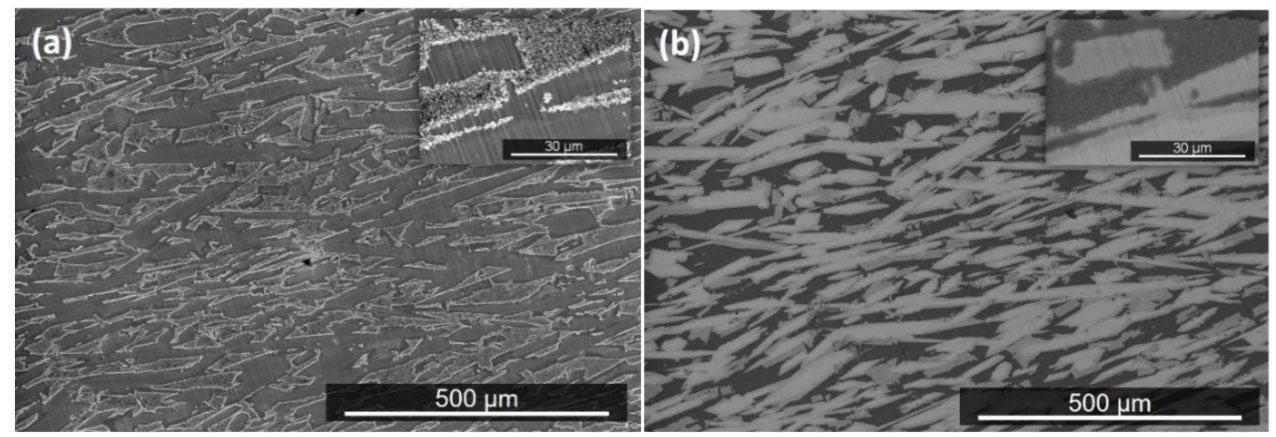

Figure 8. Scale of the alloy $\mathrm{OHC} 2$ after isothermal oxidation at $800{ }^{\circ} \mathrm{C}$ for $100 \mathrm{~h}$ : (a) SE image, (b) BSE image.

The GXRD data had peaks that corresponded to the cubic $\gamma \mathrm{Al}_{2} \mathrm{O}_{3}$ (JCPDS 29-63) and monoclinic $\theta \mathrm{Al}_{2} \mathrm{O}_{3}$, labelled $\mathrm{Al}_{2} \mathrm{O}_{3}(\mathrm{~m})$ in Figure 9 (JCPDS 35-121), monoclinic $\mathrm{Al}_{2} \mathrm{SiO}_{5}$ (JCPDS 44-27) and anorthic $\mathrm{Al}_{2} \mathrm{SiO}_{5}$, labelled $\mathrm{Al}_{2} \mathrm{SiO}_{5}$ (a) (JCPDS 11-46), $\mathrm{SiO}_{2}$ trydimite (JCPDS 82-1556), labelled $\mathrm{SiO}_{2}(\mathrm{t}), \mathrm{FeTi}_{3-x} \mathrm{O}_{x}$ (JCPDS 09-320), and tetragonal $\mathrm{TiO}_{2}$, rutile (JCPDS 82-514). The X-ray elemental maps of the scale surface showed that $\mathrm{Al}_{2} \mathrm{O}_{3}$ formed over $\mathrm{Fe}_{3} \mathrm{Al}_{2} \mathrm{Si}_{3}$ and that over the $\mathrm{FeSi}_{2} \mathrm{Ti}_{\text {formed }} \mathrm{Al}_{2} \mathrm{SiO}_{5}$ and $\mathrm{Ti}_{x} \mathrm{Fe}_{(3-x)} \mathrm{O}_{x}$ (Figure 10). Over the $\mathrm{TM}_{6} \mathrm{Si}_{5}$ formed $\mathrm{SiO}_{2}, \mathrm{Al}_{2} \mathrm{O}_{3}$, and some $(\mathrm{Ti}, \mathrm{Cr}, \mathrm{Nb}) \mathrm{O}_{2}$ rutile type oxide. 


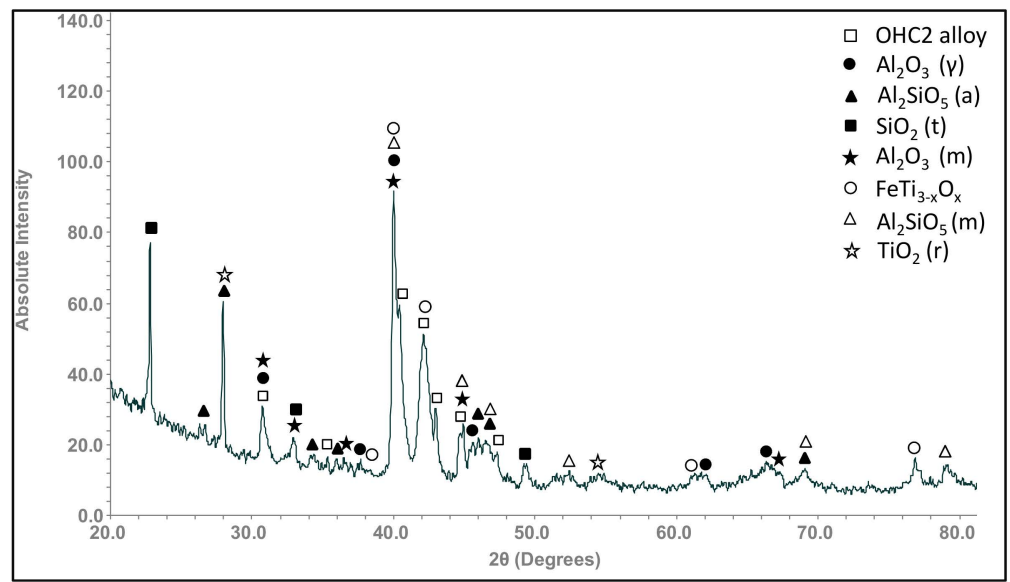

Figure 9. GXRD data $\left(\theta=5^{\circ}\right)$ for the scale formed on the alloy $\mathrm{OHC} 2$ at $800{ }^{\circ} \mathrm{C}$ for $100 \mathrm{~h}$.
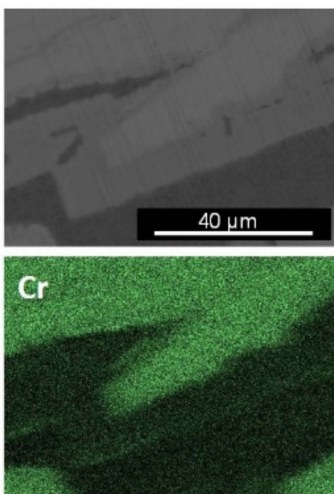

$\mathrm{Ti}$

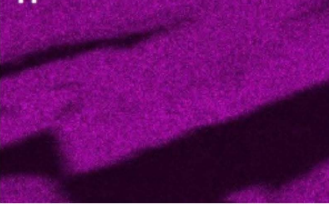

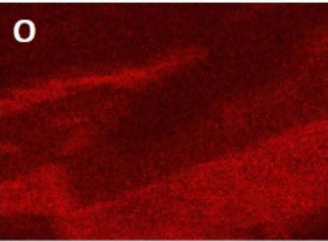

$\mathrm{Fe}$

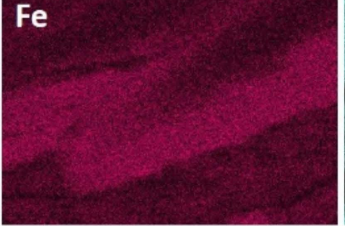

Al

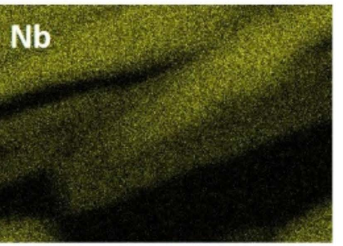

Si

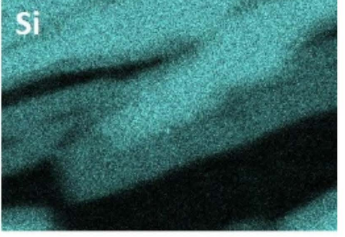

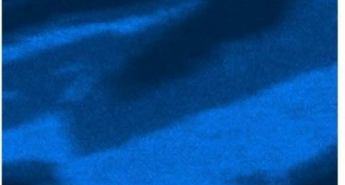

Figure 10. X-ray elemental maps of scale surface after isothermal oxidation at $800{ }^{\circ} \mathrm{C}$ for $100 \mathrm{~h}$, BSE image.

The scale was continuous and adherent all over the alloy, and the oxide that formed over the $\mathrm{TM}_{6} \mathrm{Si}_{5}$ was thin $(<1 \mu \mathrm{m})$. A cross-section of the oxidized specimen is shown in Figure 11 . $\mathrm{The}^{\mathrm{A}} \mathrm{Al}_{2} \mathrm{O}_{3}$ blade-like whiskers that formed on the surface of the oxide over the $\mathrm{Fe}_{3} \mathrm{Al}_{2} \mathrm{Si}_{3}$ phase cannot be seen in this figure because they were removed during the sample preparation. According to Kofstad [34], these oxide types grow from thick films or scales and are not in direct contact with the substrate. The BSE image in the Figure $11 \mathrm{~b}$ shows the oxide scale within the dark contrast area and a small change in the contrast of the $\mathrm{FeSi}_{2} \mathrm{Ti}$ phase, perhaps as a result of $\mathrm{Al}$ and $\mathrm{Cr}$ depletion. At the substrate/scale interface this phase presented some areas that suggested that oxygen had preferentially oxidized Al. The elemental distribution in the cross-section is shown in Figure 11c. $\mathrm{Al}_{2} \mathrm{O}_{3}$ was the main component of the scale. A continuous $\mathrm{Al}_{2} \mathrm{O}_{3}$ layer formed over the $\mathrm{FeSi}_{2} \mathrm{Ti}_{1} \mathrm{Fe}_{3} \mathrm{Al}_{2} \mathrm{Si}_{3}$, and $\mathrm{TM}_{6} \mathrm{Si}_{5}$ phases. The $\mathrm{Fe}_{3} \mathrm{Al}_{2} \mathrm{Si}_{3}$ phase can be observed at the substrate/scale interface and $\mathrm{Cr}$ enrichment at the $\mathrm{Fe}_{3} \mathrm{Al}_{2} \mathrm{Si}_{3} / \mathrm{FeSi}_{2} \mathrm{Ti}$ interface. 

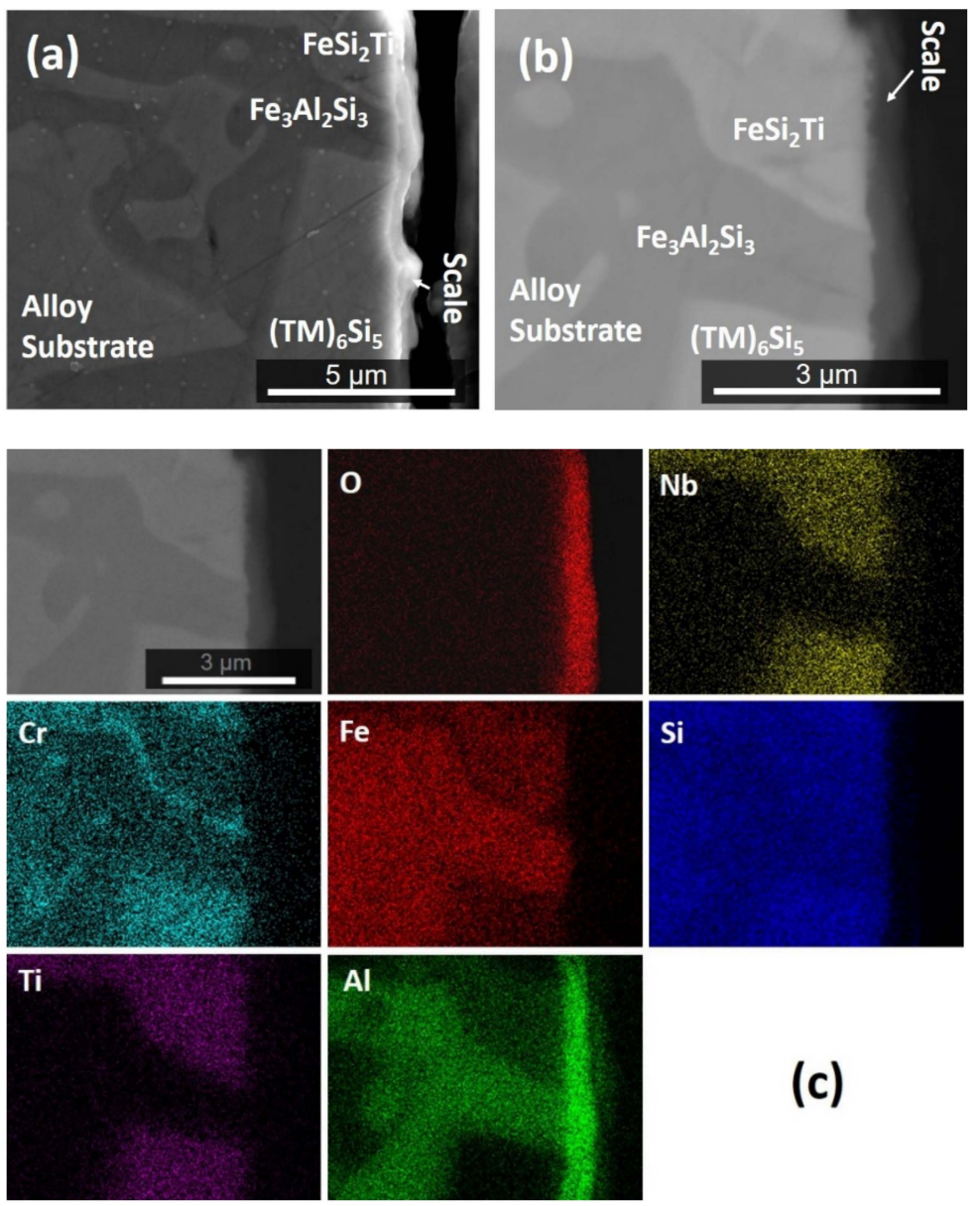

\section{(c)}

Figure 11. Cross-section of the alloy OHC2 after isothermal oxidation at $800{ }^{\circ} \mathrm{C}$ for $100 \mathrm{~h}$ : (a) SE image, (b) BSE image, (c) X-ray elemental maps.

The isothermal oxidation of the alloy at $1200{ }^{\circ} \mathrm{C}$ was not studied owing to the liquation that was observed in the heat treated specimen at the same temperature.

\section{Discussion}

\subsection{Microstructure}

In the alloy $\mathrm{OHC} 2-\mathrm{AC}$ there was macrosegregation of all the elements and Zone $\mathrm{A}$ was rich in $\mathrm{Al}$ and Fe, with about double the Al content compared with the rest of the button. This Zone A had similar thickness with the Zone A that was formed in the alloy MG7, which was also Al-rich [7]. However, unlike the latter alloy, no aluminides were formed in the Zone A of OHC2-AC. Furthermore, in the maps in Figure 1 the latter coincided with the average composition of the alloy, with the exception of the $\Delta \chi$ versus $\delta$ map, unlike the Zone A in the alloy MG7, which had parameters significantly lower than the other parts of the button [7].

The solidification microstructure indicated that the $\mathrm{TM}_{6} \mathrm{Si}_{5}$ was the primary phase, which is in agreement with the $\mathrm{Cr}-\mathrm{Ti}-\mathrm{Si}$ and $\mathrm{Cr}-\mathrm{Nb}$-Si systems [26,29]. The $\mathrm{TM}_{6} \mathrm{Si}_{5}$ can be in equilibrium with $\mathrm{TM}_{5} \mathrm{Si}_{3}$ silicides, $\mathrm{C} 40$, and B20 compounds. The latter can be in equilibrium with C40 compounds [28]. The $\mathrm{FeSi}_{2} \mathrm{Nb}$ has the same prototype as $\mathrm{FeSi}_{2} \mathrm{Ti}$ and can be in equilibrium with $\mathrm{C} 40$ and B20 compounds [27,35]. The latter (B20) can be in equilibrium with $\mathrm{Fe}_{3} \mathrm{Al}_{2} \mathrm{Si}_{3}$ [30]. The available ternary phase equilibria can account for the phases observed in OHC2-AC (for the dark phase see below), $\mathrm{OHC2}-\mathrm{HTA}$, and OHC2-HTB, and for the formation of $\mathrm{TMSi}_{2}$ in $\mathrm{OHC2}-\mathrm{HTB}$. 
The dark phase could belong to the Fe-Si-Al system, as it was essentially $\mathrm{Nb}$ - and Ti-free, and its $\mathrm{Cr}$ concentration was very low. Its composition was between those of the proposed $\tau_{10}$ and $\tau_{11}$ phases, namely $\tau_{10}=\mathrm{Al}_{9} \mathrm{Fe}_{4} \mathrm{Si}_{3}\left(\mathrm{Al}_{57-59} \mathrm{Fe}_{24-25} \mathrm{Si}_{17-18}\right)$ and $\tau_{11}=\mathrm{Al}_{4} \mathrm{Fe}_{1.7} \mathrm{Si}\left(\mathrm{Al}_{64-66.5} \mathrm{Fe}_{24-25} \mathrm{Si}_{9.5-11}\right)$ [32,36]. According to the crystallographic data for $\tau_{11}$, this phase was not present in the alloy OHC2. No crystallographic data is available for the $\tau_{10}$.

The $(\mathrm{Cr}, \mathrm{Ti})_{6} \mathrm{Si}_{5}$ is stable below $1565{ }^{\circ} \mathrm{C}$ [37], the $\mathrm{FeSi}_{2} \mathrm{Ti}$ below $1532{ }^{\circ} \mathrm{C}$ [31], and the FeSi below $1410{ }^{\circ} \mathrm{C}$ [38]. Considering the melting temperature of the $\mathrm{FeSi}$, the $\mathrm{Al}$ addition would decrease it and $\mathrm{Cr}$ would be expected to slightly increase it. The Ti content would not be expected to raise the melting temperature of $(\mathrm{Fe}, \mathrm{Cr}, \mathrm{Ti})(\mathrm{Si}, \mathrm{Al})$ above $1532{ }^{\circ} \mathrm{C}$, given that in the Si-rich region of the $\mathrm{Fe}$-Ti-Si system the TiSi is stable below $1450{ }^{\circ} \mathrm{C}$. The Al-rich $\mathrm{Fe}_{3} \mathrm{Al}_{2} \mathrm{Si}_{3}$ and DP phases would be expected to have a lower melting point. The melting temperatures of $\mathrm{Nb}_{5} \mathrm{Si}_{3}, \mathrm{Ti}_{5} \mathrm{Si}_{3}$, and $\mathrm{Cr}_{5} \mathrm{Si}_{3}$ are 2518, 2130, and $1780{ }^{\circ} \mathrm{C}$, respectively, and the $\mathrm{Fe}_{5} \mathrm{Si}_{3}$ forms via a peritectoid reaction at $1060{ }^{\circ} \mathrm{C}$ in the binary [38] and a peritectic reaction at $1201{ }^{\circ} \mathrm{C}$ in the Fe-Ti-Si. The solution of $\mathrm{Al}$ in the $\mathrm{Nb}_{5} \mathrm{Si}_{3}$ decreases the melting temperature [39]. Fe has a strong effect on the stability of the $\mathrm{TM}_{5} \mathrm{Si}_{3}$. Given that the latter was rich in $\mathrm{Ti}, \mathrm{Cr}$, and $\mathrm{Fe}$, it is suggested that the $\mathrm{TM}_{5} \mathrm{Si}_{3}$ in $\mathrm{OHC} 2$ was stable at temperatures lower than $1565{ }^{\circ} \mathrm{C}$.

The $\mathrm{TM}_{5} \mathrm{Si}_{3}$ was present at a very low volume fraction in the form of small hexagonal grains (see Figure 2e,h) that were formed either in $\mathrm{TM}_{6} \mathrm{Si}_{5}$ grains or near the interface with $\mathrm{FeSi}_{2} \mathrm{Ti}$ or $(\mathrm{Fe}, \mathrm{Cr})(\mathrm{Si}, \mathrm{Al})$. It is, therefore, possible (i) that the $\mathrm{TM}_{5} \mathrm{Si}_{3}$ was stable below $1532{ }^{\circ} \mathrm{C}$, depending on its chemical composition, and (ii) that the $\mathrm{FeSi}_{2} \mathrm{Ti}$ and $(\mathrm{Fe}, \mathrm{Cr})(\mathrm{Si}, \mathrm{Al})$ were stable below temperatures that did not differ significantly. The $\mathrm{TM}_{5} \mathrm{Si}_{3}$ was not observed in the Zone A, where the $\mathrm{TM}_{6} \mathrm{Si}_{5}$ was Fe-rich and the $\mathrm{FeSi}_{2} \mathrm{Ti}$ was $\mathrm{Nb}$-rich. This would suggest that the formation of $\mathrm{TM}_{5} \mathrm{Si}_{3}$ was linked with the partitioning of $\mathrm{Fe}$ and $\mathrm{Nb}$ in the melt, and that if the melt near the $\mathrm{TM}_{6} \mathrm{Si}_{5}$ was starved of $\mathrm{Fe}$ and $\mathrm{Nb}$ the formation of $\mathrm{TM}_{5} \mathrm{Si}_{3}$ was not possible.

The microstructure in Figure 2c shows the sequence $\mathrm{TM}_{6} \mathrm{Si}_{5}, \mathrm{FeSi}_{2} \mathrm{Ti},(\mathrm{Fe}, \mathrm{Cr})(\mathrm{Si}, \mathrm{Al}), \mathrm{Fe}_{3} \mathrm{Al}_{2} \mathrm{Si}_{3}$, and DP. The latter phases formed from the melt that surrounded the primary $\mathrm{TM}_{6} \mathrm{Si}_{5}$. The melt composition depended on the partitioning of solutes in $\mathrm{TM}_{6} \mathrm{Si}_{5}$ (Figure 4). Indeed, as the primary $\mathrm{TM}_{6} \mathrm{Si}_{5}$ silicide formed $\mathrm{Fe}$ and $\mathrm{Al}$ were rejected into the melt, while the other elements partitioned to the solid. Thus, the melt surrounding the $\mathrm{TM}_{6} \mathrm{Si}_{5}$ became richer in $\mathrm{Fe}$ and $\mathrm{Al}$ and leaner in $\mathrm{Cr}, \mathrm{Nb}$, and $\mathrm{Ti}$, and from this melt the $\mathrm{FeSi}_{2} \mathrm{Ti}$ phase formed via the peritectic reaction $\mathrm{L}+\mathrm{TM}_{6} \mathrm{Si}_{5} \rightarrow \mathrm{FeSi}_{2} \mathrm{Ti}$. The formation of the $\mathrm{TM}_{6} \mathrm{Si}_{5}, \mathrm{FeSi}_{2} \mathrm{Ti}$, and $\mathrm{TM}_{5} \mathrm{Si}_{3}$ starved the melt from $\mathrm{Nb}$ and Ti. From the Al-rich and Fe-poor melt formed the ( $\mathrm{Fe}, \mathrm{Cr})(\mathrm{Si}, \mathrm{Al})$, and then the $\mathrm{Fe}_{3} \mathrm{Al}_{2} \mathrm{Si}_{3}$ and finally the dark phase (DP).

The partitioning of $\mathrm{Nb}, \mathrm{Ti}, \mathrm{Si}$, and $\mathrm{Cr}$ was opposite of that of $\mathrm{Fe}$ and $\mathrm{Al}$ in the $\mathrm{TM}_{6} \mathrm{Si}_{5}$. The partitioning coefficients of the elements were approximately $k_{\mathrm{o}}{ }^{\mathrm{Nb}}=2.3, k_{\mathrm{o}}{ }^{\mathrm{Si}}=1.1, k_{\mathrm{o}}{ }^{\mathrm{Cr}}=1.3$, $k_{\mathrm{o}}{ }^{\mathrm{Ti}}=1.5, k_{\mathrm{o}}{ }^{\mathrm{Al}}=0.14$, and $k_{\mathrm{o}} \mathrm{Fe}=0.5$. Compared with the $\mathrm{TM}_{6} \mathrm{Si}_{5}$ phase in the alloy OHC1, the partitioning coefficients of $\mathrm{Fe}$ and $\mathrm{Cr}$ had decreased and that of Ti had increased.

Near the bottom of the button, the volume fraction of the $\mathrm{TM}_{6} \mathrm{Si}_{5}$ was lower. Compared with the bulk and top of the button, the melt that solidified in these area was richer in $\mathrm{Nb}, \mathrm{Cr}, \mathrm{Ti}, \mathrm{Si}, \mathrm{Al}$, and $\mathrm{Fe}$. It is suggested that the melt composition had shifted close to the ternary eutectic $\mathrm{L} \rightarrow \mathrm{Nb}$-rich $\mathrm{FeSi}_{2} \mathrm{Ti}+$ $\mathrm{Fe}_{3} \mathrm{Al}_{2} \mathrm{Si}_{3}+\mathrm{DPEu}$ that was formed in this part of OHC2-AC. Compared with the alloy OHC1, the new phases in the alloy $\mathrm{OHC} 2$ were the $\mathrm{TM}_{5} \mathrm{Si}_{3}$ and $\mathrm{Fe}_{3} \mathrm{Al}_{2} \mathrm{Si}_{3}$ compounds. In both alloys eutectics that contained the $\mathrm{FeSi}_{2} \mathrm{Ti}$ phase formed in the bottom of the cast buttons, but a ternary rather than a binary eutectic was formed in the alloy $\mathrm{OHC} 2$.

The $\mathrm{Ti}_{5} \mathrm{Si}_{3}, \mathrm{CrSi}_{2}$, and $\mathrm{Cr}_{5} \mathrm{Si}_{3}$ silicides exhibit solubilities for third elements [37]. The solubility of $\mathrm{Nb}$ in $\mathrm{Ti}_{5} \mathrm{Si}_{3}$ and $\mathrm{Cr}_{5} \mathrm{Si}_{3}$ has been reported in previous studies [40-43]. Solubility of 23 at.\% $\mathrm{Nb}$ in the $\mathrm{Ti}_{5} \mathrm{Si}_{3}$ has been reported in the temperature range 500 to $1200{ }^{\circ} \mathrm{C}$, and no $\mathrm{Nb}$ solubility in the $\mathrm{Cr}_{5} \mathrm{Si}_{3}$. The solubility of $\mathrm{Fe}$ in $\mathrm{Ti}_{5} \mathrm{Si}_{3}$ is 4 at.\% at $900{ }^{\circ} \mathrm{C}$ [31] and the solubility of $\mathrm{Fe}$ in $\mathrm{Cr}_{5} \mathrm{Si}_{3}$ is 4.5 at.\% at $950{ }^{\circ} \mathrm{C}$ [44]. The $\mathrm{Al}$ solubility in $\mathrm{Cr}_{5} \mathrm{Si}_{3}$ is about 2.0 at. $\%$ at $800{ }^{\circ} \mathrm{C}$ [45] and in $\mathrm{Ti}_{5} \mathrm{Si}_{3}$ is about 12 at.\% at $1000{ }^{\circ} \mathrm{C}$ [46]. The solubilities of elements that substitute $\mathrm{Nb}$ and $\mathrm{Si}$ in $\mathrm{Nb}_{5} \mathrm{Si}_{3}$ were discussed in a previous study [23]. The solubilities of $\mathrm{Fe}$ and $\mathrm{Cr}$ in $\mathrm{Nb}_{5} \mathrm{Si}_{3}$ silicide are very small [47]. In this work, 
the concentrations of $\mathrm{Al}$ and $\mathrm{Nb}$ in $\mathrm{TM}_{5} \mathrm{Si}_{3}$ were in agreement with reported solubilities, but the $\mathrm{Fe}$ content was higher than the reported values. The latter would suggest that in the presence of $\mathrm{Al}$ and $\mathrm{Nb}$ the solubility of $\mathrm{Fe}$ in $\mathrm{TM}_{5} \mathrm{Si}_{3}$ was increased up to 8.7 at.\%.

In the $\mathrm{Fe}_{3} \mathrm{Al}_{2} \mathrm{Si}_{3}$ phase the $\mathrm{Al}$ content was in the range of 28.6 to 34.2 at.\%. Considering the $\mathrm{Al}$ and $\mathrm{Si}$ contents in the $\mathrm{Fe}_{3} \mathrm{Al}_{2} \mathrm{Si}_{3}$ phase separately, and $\mathrm{Cr}$ with $\mathrm{Fe}$, the composition of $\mathrm{Fe}_{3} \mathrm{Al}_{2} \mathrm{Si}_{3}$ was within the composition range of $\tau_{1}=\mathrm{Fe}_{3} \mathrm{Al}_{2} \mathrm{Si}_{3}\left(\mathrm{Al}_{21.5-45} \mathrm{Fe}_{36.5-37.5} \mathrm{Si}_{8.5-41.5}\right)$ reported in a previous study [32]. The $\mathrm{Fe}_{3} \mathrm{Al}_{2} \mathrm{Si}_{3}$ had a limited solubility for $\mathrm{Cr}$ that substituted $\mathrm{Fe}$, and negligible solubility for $\mathrm{Nb}$ and Ti. Marker et al. [36] noted the unusual combination of the broad homogeneity range of $\mathrm{Fe}_{3} \mathrm{Al}_{2} \mathrm{Si}_{3}$ with its very low symmetry crystal structure (triclinic). They suggested that this phase should be described as $\mathrm{Fe}_{3} \mathrm{Al}_{2+x} \mathrm{Si}_{3-x}$ with $-0.3<x<1.3$ instead of $\mathrm{Fe}_{3} \mathrm{Al}_{2} \mathrm{Si}_{3}$.

The $\mathrm{TMSi}_{2}$ had $\mathrm{Si}+\mathrm{Al}=65.7$ at.\%. According to Chen et al. [45], the solubility of $\mathrm{Al}$ in $\mathrm{CrSi}_{2}$ is up to 25 at.\%, which is consistent with the $\mathrm{Al}$ content of $\mathrm{TMSi}_{2}$. It is suggested that $\mathrm{Al}$ enhanced the solubility of Fe and Ti in this phase, because according to Lindholm [44], the $\mathrm{CrSi}_{2}$ phase does not dissolve Fe.

The $\mathrm{FeSi}_{2} \mathrm{Ti}$ had $(\mathrm{Si}+\mathrm{Al}) \approx 50$ at.\%. After the heat treatments, its composition moved closer to the values given in a previous study [31] for the $\tau_{1}\left(\mathrm{FeSi}_{2} \mathrm{Ti}\right.$ ) phase (considering $\mathrm{Nb}, \mathrm{Ti}$, and $\mathrm{Cr}$ together). Indeed, the compositions of the $\mathrm{FeSi}_{2} \mathrm{Ti}$ in the cast and heat treated conditions gave it as $(\mathrm{Al}+\mathrm{Si})_{50-52} \mathrm{Fe}_{23-25}(\mathrm{Ti}+\mathrm{Nb}+\mathrm{Cr})_{24-26}$, which is consistent with the $\left.\tau_{1}=\mathrm{FeSi}_{2} \mathrm{Ti}_{(\mathrm{Si}} \mathrm{Si}_{4-50} \mathrm{Fe}_{24-25} \mathrm{Ti}_{25-26}\right)$ phase in the Ti-Fe-Si system [31]. Unlike the alloy OHC1-AC, the FeSi $\mathrm{Ti}_{2}$ in OHC2 had up to 5.2 at.\% $\mathrm{Nb}$ and 13.8 at.\%Al, which would suggest that the presence of $\mathrm{Al}$ enhanced the $\mathrm{Nb}$ solubility in $\tau_{1}$. The $\mathrm{Al}$ and $\mathrm{Cr}$ solubilities in the $\tau_{1}$ decreased at higher temperature, which was also observed for $\mathrm{Cr}$ in the alloy OHC1-AC [9].

The $(\mathrm{Fe}, \mathrm{Cr})(\mathrm{Si}, \mathrm{Al})$ had $\mathrm{Si}+\mathrm{Al}$ about 50 at.\% and high Fe solubility. The $\mathrm{CrSi}$ and $\mathrm{FeSi}$ are isostructural and have complete solubility but do not show ternary solubilities for $\mathrm{Ti}$ and $\mathrm{Nb}$ [44]. A limited Ti solubility of 1 at.\% in FeSi was reported by Marker et al. [48], while Du and Shuster [37] reported negligible ternary solubilities in TiSi and $\mathrm{CrSi}$. Moreover, about 2 at. $\% \mathrm{Al}$ can be in solution in the CrSi phase according to the isothermal sections at 800 and $1100{ }^{\circ} \mathrm{C}$ of the $\mathrm{Al}-\mathrm{Cr}$-Si system $[45,49]$. Compared with the composition of the (Fe,Cr,Ti)Si phase in the alloy OHC1 [9], the Ti content in the $(\mathrm{Fe}, \mathrm{Cr})(\mathrm{Si}, \mathrm{Al})$ in $\mathrm{OHC} 2$ was even lower. This phase had $\mathrm{Cr}$ in the range 7.9 to $9.2 \mathrm{at} . \%$ and up to $8.5 \mathrm{at} . \%$ $\mathrm{Al}$. The $\mathrm{Al}$ content in $(\mathrm{Fe}, \mathrm{Cr})(\mathrm{Si}, \mathrm{Al})$ was in good agreement with the $\mathrm{Al}$ solubility in $\mathrm{FeSi}$ (about 12 at.\%) at 800 and $900{ }^{\circ} \mathrm{C}$ that was reported by Marker et al. [36,48]. After the heat treatment at $950{ }^{\circ} \mathrm{C}$ the $(\mathrm{Fe}, \mathrm{Cr})(\mathrm{Si}, \mathrm{Al})$ was not stable in the alloy OHC2. The same was the case for the DP phase.

\subsection{Oxidation}

At $800{ }^{\circ} \mathrm{C}$ the oxidation of the alloy OHC2 was better compared with the alloy OHC1 [9]. It had gained less than $20 \%$ of the weight gained by $\mathrm{OHC} 1$ [9] and its oxidation followed parabolic kinetics after the first hour. The TGA data (Figure 7) showed consecutive very small weight changes, significantly smaller compared with the alloy $\mathrm{OHC1}$ [9]. Continuous reaction with oxygen could change the microstructure of the scale with the resulting volume changes, causing some cracking in it. The alloy showed its capability to self-heal after weight loss. This was attributed to the $\mathrm{Al}$ addition and the oxidation of the main phases $(\mathrm{TM})_{6} \mathrm{Si}_{5}, \mathrm{FeSi}_{2} \mathrm{Ti}$, and $\mathrm{Fe}_{3} \mathrm{Al}_{2} \mathrm{Si}_{3}$ that formed different oxidation products in a very thin scale. There was no significant elemental depletion at the substrate/scale interface in these phases.

The oxidation was sub-parabolic with high oxidation rate in the first hour, followed by parabolic oxidation at a low rate. This behavior has been found in alumina-forming superalloys [50-52]. The sub-parabolic time dependence of scale growth is related to lower temperatures, and is attributed to grain-boundary-linked mechanisms (short-circuit) where fast oxygen penetration occurs, initially resulting in a high oxidation rate and then, as the oxide grows, the easy oxygen paths are blocked and the oxidation slows down [50]. 
As was the case in the alumina forming superalloys, the $\gamma \mathrm{Al}_{2} \mathrm{O}_{3}$ and $\theta \mathrm{Al}_{2} \mathrm{O}_{3}$ were formed in the alloy OHC2. In the case of the superalloys, the $\alpha \mathrm{Al}_{2} \mathrm{O}_{3}$ was formed after an extended oxidation period (more than $100 \mathrm{~h}$ ). The transformation of $\gamma \mathrm{Al}_{2} \mathrm{O}_{3}$ to $\theta \mathrm{Al}_{2} \mathrm{O}_{3}$ has been observed in the temperature range 800 to $1000{ }^{\circ} \mathrm{C}$ in $\mathrm{NiAl}$ alloys [53].

According to the GXRD data, the other oxides that were present in the scale together with the $\gamma \mathrm{Al}_{2} \mathrm{O}_{3}$ (main oxide) and $\theta \mathrm{Al}_{2} \mathrm{O}_{3}$ were $\mathrm{SiO}_{2}, \mathrm{Al}_{2} \mathrm{SiO}_{5}, \mathrm{FeTi}_{3-x} \mathrm{O}_{x}$, and $\mathrm{TiO}_{2}$ (Figure 9). The X-ray elemental maps (Figure 11c) also confirmed the presence of $\mathrm{Al}_{2} \mathrm{O}_{3}$ in the scale. When $\gamma \mathrm{Al}_{2} \mathrm{O}_{3}$ was found to be the main oxide on $\mathrm{NiAl}$ alloys at $800{ }^{\circ} \mathrm{C}$, the diffusion mechanism was linked with its modification [53]. The other oxides formed in the scale of the alloy $\mathrm{OHC} 2$ could have contributed to the $\gamma \mathrm{Al}_{2} \mathrm{O}_{3} \rightarrow \theta \mathrm{Al}_{2} \mathrm{O}_{3}$ transformation.

There is no data about the oxidation of the $\mathrm{TM}_{6} \mathrm{Si}_{5}$ phase with $\mathrm{Al}$ additions. According to this work, the low $\mathrm{Al}$ content in the $\mathrm{TM}_{6} \mathrm{Si}_{5}$ was enough to form $\mathrm{Al}_{2} \mathrm{O}_{3}$ over it. It is also likely that the $\mathrm{Al}_{2} \mathrm{O}_{3}$ formed over this phase could have different thicknesses owing to the partitioning of $\mathrm{Al}$, the concentration of which was higher at the edges (Figure 4), and that the partitioning of $\mathrm{Al}$ could be linked with the growth of aluminum silicates, such as $\mathrm{Al}_{2} \mathrm{SiO}_{5}$, and $\mathrm{SiO}_{2}$ over the bulk of $\mathrm{TM}_{6} \mathrm{Si}_{5}$ (Figure 10). It is also likely that over the bulk of the $\mathrm{TM}_{6} \mathrm{Si}_{5}$ other oxides such as $\mathrm{TiO}_{2}$ had grown, allowing Si mobility towards the surface, as was discussed for the oxidation of the $\mathrm{TM}_{6} \mathrm{Si}_{5}$ phase in the alloy $\mathrm{OHC1}$ [9], where the main oxidation products were $\mathrm{TiO}_{2}, \mathrm{SiO}_{2}$, and $\mathrm{Fe}_{2} \mathrm{O}_{3}$. $\mathrm{Al}_{2} \mathrm{O}_{3}$ whiskers formed on the top of the scale that developed over the $\mathrm{Fe}_{3} \mathrm{Al}_{2} \mathrm{Si}_{3}$. The growth of whiskers on top of the scale that grew on NiAl-based alloys was attributed to the $\gamma \mathrm{Al}_{2} \mathrm{O}_{3} \rightarrow \theta \mathrm{Al}_{2} \mathrm{O}_{3}$ transformation [53].

Novák et al. [54] suggested that Fe-Si-Al alloys mainly form $\delta \mathrm{Al}_{2} \mathrm{O}_{3}$ with some $\mathrm{Fe}_{2} \mathrm{O}_{3}$ when oxidized at $800{ }^{\circ} \mathrm{C}$, and that the $\mathrm{Fe}_{2} \mathrm{O}_{3}$ content in the scale decreases when the Si content in the alloys is greater than 20 at.\%. In the scale of the alloy $\mathrm{OHC} 2$, the $\delta \mathrm{Al}_{2} \mathrm{O}_{3}$ was not confirmed by the GXRD. The Si content in $\mathrm{Fe}_{3} \mathrm{Al}_{2} \mathrm{Si}_{3}$ was above 30 at.\% and there was some Fe enrichment at the substrate/scale interface, which could suggest the possible formation of Fe oxide(s) just below the $\mathrm{Al}_{2} \mathrm{O}_{3}$ scale. The GXRD did not confirm this. It is suggested that under isothermal oxidation in air at $800{ }^{\circ} \mathrm{C}$, the $\mathrm{Fe}_{3} \mathrm{Al}_{2} \mathrm{Si}_{3}$ formed an Fe-oxide followed by $\gamma \mathrm{Al}_{2} \mathrm{O}_{3}$, and then $\theta \mathrm{Al}_{2} \mathrm{O}_{3}$ whiskers formed at the oxide/gas interface.

In the alloy $\mathrm{OHC1}, \mathrm{TiO}_{2}$ and $\mathrm{SiO}_{2}$ formed over the $\mathrm{FeSi}_{2} \mathrm{Ti}$ [9]. This phase exhibited solubility of $\mathrm{Al}$ in the alloy $\mathrm{OHC} 2$. This would explain the presence of $\mathrm{Al}_{2} \mathrm{O}_{3}, \mathrm{Al}_{2} \mathrm{SiO}_{5}$, and $\mathrm{FeTi}_{3-x} \mathrm{O}_{x}$ oxides over it (Figure 9). The $\mathrm{X}$-ray elemental maps in Figure 11c showed that $\mathrm{Al}_{2} \mathrm{O}_{3}$ was the main oxidation product. Below the areas where $\mathrm{Al}_{2} \mathrm{O}_{3}$ was formed there might have been some oxygen penetration. Thus, it is likely that the diffusion of oxygen in $\mathrm{Al}_{2} \mathrm{O}_{3}$ allowed the oxidation of $\mathrm{Fe}, \mathrm{Ti}$, and $\mathrm{Si}$ beneath it. Pownceby et al. [55] reported a miscibility gap between $\mathrm{Fe}_{2} \mathrm{O}_{3}$ and $\mathrm{Al}_{2} \mathrm{O}_{3}$, but they also found some solubility of $\mathrm{Fe}$ in $\mathrm{Al}_{2} \mathrm{O}_{3}$ at low temperatures. Thus, it is likely that some Fe was in solution in $\mathrm{Al}_{2} \mathrm{O}_{3}$. This could explain the Fe signal in the X-ray maps in Figure 10 and the absence of Fe oxide in the GXRD diffractogram (Figure 9).

\section{Summary and Concluding Remarks}

The microstructure and isothermal oxidation at $800{ }^{\circ} \mathrm{C}$ of the silicide based alloy $\mathrm{Si}-22 \mathrm{Fe}-12 \mathrm{Cr}-12 \mathrm{Al}-10 \mathrm{Ti}-5 \mathrm{Nb}$ (OHC2) were studied. The cast alloy exhibited macrosegregation of all elements. The microstructures in the cast alloy and after the heat treatment at $800{ }^{\circ} \mathrm{C}$ consisted of the same phases, namely $\mathrm{TM}_{6} \mathrm{Si}_{5}, \mathrm{TM}_{5} \mathrm{Si}_{3}, \mathrm{FeSi}_{2} \mathrm{Ti}_{2} \mathrm{Fe}_{3} \mathrm{Al}_{2} \mathrm{Si}_{3},(\mathrm{Fe}, \mathrm{Cr})(\mathrm{Si}, \mathrm{Al})$, and an unknown phase of dark contrast (the dark phase (DP)). The latter two phases were not stable at $950{ }^{\circ} \mathrm{C}$, where the $\mathrm{TMSi}_{2}$ was formed. There was evidence of endothermic reaction (s) below $1200^{\circ} \mathrm{C}$ and liquation of the specimen that was heat treated at $1200^{\circ} \mathrm{C}$. The alloy followed parabolic oxidation kinetics after the first hour of isothermal oxidation at $800{ }^{\circ} \mathrm{C}$, did not pest, and formed a self-healing scale, in which the dominant oxide was $\mathrm{Al}_{2} \mathrm{O}_{3}$. 
The objective of this research was to find out what the effect of $\mathrm{Al}$ addition would be on the microstructure and oxidation of an alloy of the Si-Fe-Cr-Ti-Nb system. The alloy OHC2 was designed with the constraint and requirements that were discussed in the Section 2.

Unlike the alloy $\mathrm{OHC1}$, the alloy $\mathrm{OHC} 2$ suffered from liquation after the heat treatment at $1200{ }^{\circ} \mathrm{C}$. There was evidence for incipient melting in the former alloy [9] and also in the latter. On this evidence, the suitability of both alloys for BCs for $\mathrm{Nb}$-silicide-based alloys is questionable. Furthermore, the experimental results of the alloy $\mathrm{OHC} 2$ would suggest that the high temperature stability of silicide-based Si-Fe-Cr-Ti-Nb coating alloys would be decreased by the addition of Al via alloying or interdiffusion. In our opinion, this eliminates silicide $\mathrm{Si}-\mathrm{Fe}-\mathrm{Cr}-\mathrm{Ti}-\mathrm{Nb}$ alloys based on the composition of $\mathrm{OHC} 1$ as $\mathrm{BC}$ components of an environmentally resistant coating for $\mathrm{Nb}$-silicide-based alloys.

The data in this work and in a previous study [9] for non-pesting silicide-based Si-Fe-Cr-Ti-Nb alloys with and without $\mathrm{Al}$ addition would suggest that the parameters VEC and $\delta$ were important regarding the formation of $\mathrm{SiO}_{2}, \mathrm{Cr}_{2} \mathrm{O}_{3}$, and $\mathrm{TiO}_{2}$ scale or $\mathrm{Al}_{2} \mathrm{O}_{3}$ scale at $800{ }^{\circ} \mathrm{C}$ (see Figure $1 \mathrm{~d}$ and compare it with the Figure $23 \mathrm{~d}$ in the previous study [9]). Indeed, the parameter $\Delta x$ cannot differentiate between the alloys OHC1 and OHC2 (Figure 1b,c). It is suggested that the "critical" values of the alloy parameters VEC and $\delta$ for "changing" between alumina and non-alumina scales at $800{ }^{\circ} \mathrm{C}$ should be in the narrow ranges indicated, respectively, by the yellow and green color boxes in Figure 1a,b,d. Further research is needed to verify this. Additionally, Figure $1 \mathrm{~d}$ indicates that if a multi-material $\mathrm{BC}$ were to be built with layers consisting of non-pesting and $\mathrm{Al}_{2} \mathrm{O}_{3}$ scale forming intermetallic alloys of the $\mathrm{Si}-\mathrm{Fe}-\mathrm{Cr}-\mathrm{Ti}-\mathrm{Nb}-\mathrm{Al}$ and $\mathrm{Nb}-\mathrm{Si}-\mathrm{Ti}-\mathrm{Al}-\mathrm{Hf}$ systems, the values of the parameter $\delta$ of $\mathrm{Nb}-\mathrm{Si}$-Ti-Al-Hf intermetallic alloys that form Zone A would be in the same range as those of silicide Si-Fe-Cr-Ti-Nb alloys that do not form $\mathrm{Al}_{2} \mathrm{O}_{3}$ scale. We would like to suggest that $\mathrm{VEC}$ should be the key parameter to use to design and select non-pesting $\mathrm{BC}$ alloys.

The Fe-free silicide alloy $\mathrm{OHC} 5$ of the Si-Cr-Ti-Nb-Al system did not pest at $800{ }^{\circ} \mathrm{C}$ and formed $\mathrm{Al}_{2} \mathrm{O}_{3}$ scale at this temperature and at $1200{ }^{\circ} \mathrm{C}$ [9]. Being conscious of the fact that the experimental data is limited, we would like to suggest that Fe-free intermetallic alloys of the Nb-Si-Ti-Al-Hf and $\mathrm{Si}-\mathrm{Cr}-\mathrm{Ti}-\mathrm{Nb}-\mathrm{Al}$ systems could be components of a layered multi-material BC of an environmentally resistant coating and that their design(selection) could use the parameters $\delta, \Delta x$, and VEC, with values restricted to be in the ranges shown by the vertical and horizontal dashed lines and arrows in Figure 1 .

Author Contributions: Experimental work, O.H.-N.; formal analysis of data, O.H.-N., P.T.; draft preparation of paper, O.H.-N.; writing, review and editing, O.H.-N., P.T.; supervisor, P.T.

Funding: The support of this work by the University of Sheffield, Rolls-Royce Plc, and EPSRC (EP/H500405/1, EP/L026678/1) is gratefully acknowledged.

Acknowledgments: Financial support to O.H.-N. by the National Research and Technology Council of Mexico (CONACyT) and the Robert Rocca Education Programme is also gratefully acknowledged.

Conflicts of Interest: The authors declare no conflict of interest.

\section{References}

1. Subramanian, P.; Mendiratta, M.; Dimiduk, D.; Stucke, M. Advanced intermetallic alloys—beyond gamma titanium aluminides. Mater. Sci. Eng. A 1997, 239, 1-13. [CrossRef]

2. Bewlay, B.P.; Jackson, M.R.; Subramanian, P.R.; Zhao, J.-C. A review of very-high-temperature Nb-silicide-based composites. Met. Mater. Trans. A 2003, 34, 2043-2052. [CrossRef]

3. Tsakiropoulos, P. On Nb Silicide Based Alloys: Alloy Design and Selection. Materials 2018, 11, 844. [CrossRef] [PubMed]

4. Jackson, M.R.; Rowe, R.G.; Skelly, D.W. Oxidation of some intermetallic compounds and intermetallic matrix composites. MRS Online Proc. Lib. Arch. 1995, 364, 1339. [CrossRef]

5. Bewlay, B.; Jackson, M.; Zhao, J.-C. Coatings, Method of Manufacture and the articles Derived Therefrom. U.S. Patent US6767653B2, 27 July 2004.

6. Olson, G.B.; Bryan, D.J.; Misra, A. Oxidation Resistant Niobium Based Alloys. U.S. Patent 2006/0172142A1, 3 August 2006. 
7. Ghadyani, M.; Utton, C.; Tsakiropoulos, P. Microstructures and isothermal oxidation of the alumina scale forming $\mathrm{Nb}_{1.7} \mathrm{Si}_{2.4} \mathrm{Ti}_{2.4} \mathrm{Al}_{3} \mathrm{Hf}_{0.5}$ and $\mathrm{Nb}_{1.3} \mathrm{Si}_{2.4} \mathrm{Ti}_{2.4} \mathrm{Al}_{3.5} \mathrm{Hf}_{0.4}$ alloys. Materials 2019, 12, 222. [CrossRef] [PubMed]

8. Ghadyani, M.; Utton, C.; Tsakiropoulos, P. Microstructures and isothermal oxidation of the alumina scale forming Nb1.45Si2.7Ti2.25Al3.25Hf0.35 and Nb1.35Si2.3Ti2.3Al3.7Hf0.35 alloys. Materials 2019, 12, 759. [CrossRef]

9. Hernández-Negrete, O.; Tsakiropoulos, P. On the microstructure and isothermal oxidation of silica and alumina scale forming Si-23Fe-15Cr-15Ti-1Nb and Si-25Nb-5Al-5Cr-5Ti (at.\%) silicide alloys. Materials 2019, 12, 1091. [CrossRef]

10. Jackson, M.R.; Ritter, A.M. Oxidation-Resistant Coating for Niobium-Base Alloys. U.S. Patent 5721061A, 24 February 1998.

11. National Research Council (US). Committee on Coatings. High-Temperature Oxidation-Resistant Coatings: Coatings for Protection from Oxidation of Superalloys, Refractory Metals, and Graphite; National Academies: Washington, DC, USA, 1970; ISBN 978-0-309-01769-5. [CrossRef]

12. Kirkwood, B.L.; Picha, E.M.W. Silica-Enriched Protective Coating for Hypersonic Flight Vehicles and Method of Applying Same, Including Field Repair. U.S. Patent 5431961A, 11 July 1995.

13. Weber, R.; Bouvier, J.; Slama, G. Failure mechanisms of aluminide and silicide coatings on a niobium alloy subjected to thermal cycling in air. J. Less-Common Met. 1973, 32, 1-20. [CrossRef]

14. Wahl, G. Coating composition and the formation of protective oxide layers at high temperatures. Thin Solid Films 1983, 107, 417-426. [CrossRef]

15. Tsirlin, M.S.; Anurova, G.M.; Aliev, A.D. Structure and oxidation resistance of a slurry-diffusion coating on Nb. Powder Metall. Met. Ceram. 1981, 20, 801-804.

16. Portebois, L.; Mathieu, S.; Knittel, S.; Aranda, L.; Vilasi, M. Protective coatings for niobium alloys: Manufacture, characterization and oxidation behaviour of $(\mathrm{TiXCr})_{7} \mathrm{Si}_{6}$ with $X=\mathrm{Fe}, \mathrm{Co}$ and Ni. Oxid. Met. 2013, 80, 243-255. [CrossRef]

17. Adachi, T.; Meier, G.H. Oxidation of iron-silicon alloys. Oxid. Met. 1987, 27, 347-366. [CrossRef]

18. Tian, X.; Guo, X. Oxidation behaviour of an Al-modified silicide coating on an Nb-silicide based ultrahigh-temperature alloy. Corrosion 2010, 66, 025003-025003-6. [CrossRef]

19. Zhang, P.; Guo, X. Preparation and oxidation resistance of silicide/aluminide composite coatings on an $\mathrm{Nb}-\mathrm{Ti}-\mathrm{Si}$ based alloy. Surf. Coat. Technol. 2015, 274, 18-25. [CrossRef]

20. Zhang, H.; Yuan, S.N.; Zhou, C.G.; Sha, J.B.; Zhao, X.Q.; Jia, L.N. Research progress on ultra-high-temperature Nb-silicide-based alloys. Acta Aeronaut. Astronaut. Sin. 2014, 35, 2756-2766.

21. Zhao, J.-C.; Jackson, M.R.; Bewlay, B.P. Oxidation Resistant Coatings for Niobium Based Silicide Composites. U.S. Patent 6,645,560 B2, 11 November 2003.

22. Jackson, M.R.; Subramanian, P.; Zhao, J.-C.; Bewlay, B.P.; Darolia, R.; Schafrik, R. Turbine Blade for Extreme Temperature Conditions. U.S. Patent 7189459B2, 13 March 2007.

23. Tsakiropoulos, P. On the alloying and properties of tetragonal Nb5Si3 in Nb-silicide based alloys. Materials 2018, 11, 69. [CrossRef] [PubMed]

24. Tsakiropoulos, P. Alloying and properties of $\mathrm{C} 14-\mathrm{NbCr} 2$ and $\mathrm{A} 15-\mathrm{Nb} 3 X(X=\mathrm{Al}, \mathrm{Ge}, \mathrm{Si}, \mathrm{Sn})$ in Nb-silicidebased alloys. Materials 2018, 11, 395. [CrossRef]

25. Tsakiropoulos, P. Alloying and Hardness of eutectics with Nbss and Nb5Si3 in Nb-silicide based alloys. Materials 2018, 11, 592. [CrossRef]

26. Lysenko, L.A.; Markiv, V.Y.; Tsybukh, O.V.; Gladyshevski, E.I. The system titanium-chromium-silicon. Inorg. Mater. 1971, 7, 157-159.

27. Raghavan, V. The Fe-Si-Ti (iron-silicon-titanium) system, phase diagrams ternary iron alloys, Indian Inst. Met. 1987, 1, 65-72.

28. Raghavan, V. The Cr-Fe-Si (chromium-iron-silicon) system, phase diagrams ternary iron alloys. Indian Inst. Met. 1987, 1, 31-42.

29. David, N.; Cartigny, Y.; Belmonte, T.; Fiorani, J.; Vilasi, M. Thermodynamic description of the $\mathrm{Cr}-\mathrm{Nb}-\mathrm{Si}$ isothermal section at $1473 \mathrm{~K}$. Intermetallics 2006, 14, 464-473. [CrossRef]

30. Ghosh, G. Aluminium-Iron-Silicon, Ternary Alloys; VCH: Weinheim, Germany, 1992.

31. Weitzer, F.; Schuster, J.C.; Naka, M.; Stein, F.; Palm, M. On the reaction scheme and liquidus surface in the ternary system Fe-Si-Ti. Intermetallics 2008, 16, 273-282. [CrossRef] 
32. Krendelsberger, N.; Weitzer, F.; Schuster, J.C. On the Reaction Scheme and Liquidus Surface in the Ternary System Al-Fe-Si. Met. Mater. Trans. B 2007, 38, 1681-1691. [CrossRef]

33. Kofstad, P. High Temperature Oxidation of Metals; John Wiley \& Son: New York, NY, USA, 1966.

34. Kofstad, P. High-Temperature Oxidation; Elsevier: London, UK, 1988.

35. Raghavan, V.; Ghosh, G. The Fe-Nb-Si (iron-niobium-silicon) system. Trans. Indian Inst. Met. 1984, 37, 421-425.

36. Marker, M.C.; Skolyszewska-Kühberger, B.; Effenberger, H.S.; Schmetterer, C.; Richter, K.W. Phase equilibria and structural investigations in the system Al-Fe-Si. Intermetallics 2011, 19, 1919-1929. [CrossRef] [PubMed]

37. Du, Y.; Schuster, J.C. Experimental investigation and thermodynamic description of the Cr-Si-Ti system. Scand. J. Met. 2002, 31, 25-33. [CrossRef]

38. ASM Alloy Phase Diagram Database, Editor in Chief P Villars, Section Editors H Okamoto, K Cenzual, 2006-2019. Available online: https://matdata.asminternational.org/apd/index.aspx (accessed on 3 June 2019).

39. Shao, G. Thermodynamic assessment of the $\mathrm{Nb}-\mathrm{Si}-\mathrm{Al}$ system. Intermetallics 2004, 12, 655-664. [CrossRef]

40. Bewlay, B.P.; Jackson, M.R.; Lipsitt, H.A. The Nb-Ti-Si ternary phase diagram: Evaluation of liquid- solid phase equilibria in Nb-and Ti-rich alloys. J. Phase Equilibria Diffus. 1997, 18, 264-278. [CrossRef]

41. Zhan, Y.; Sun, Z.; Jiang, J.; Ma, J.; Zhang, X.; Zhuang, Y. The 773K isothermal section of the ternary phase diagram of the $\mathrm{Nb}-\mathrm{Ti}-\mathrm{Si}$ system. J. Alloy Compd. 2009, 468, 150-153. [CrossRef]

42. Zhao, J.-C.; Jackson, M.; Peluso, L. Determination of the $\mathrm{Nb}-\mathrm{Cr}-\mathrm{Si}$ phase diagram using diffusion multiples. Acta Mater. 2003, 51, 6395-6405. [CrossRef]

43. Shao, G. Thermodynamic modelling of the $\mathrm{Cr}-\mathrm{Nb}-\mathrm{Si}$ system. Intermetallics 2005, 13, 69-78. [CrossRef]

44. Lindholm, M. A thermodynamic description of the Fe-Cr-Si system with emphasis on the equilibria of the sigma (G) phase. J. Phase Equilib. 1997, 18, 432. [CrossRef]

45. Chen, H.-L.; Weitzer, F.; Schuster, J.C.; Du, Y.; Xu, H. The Isothermal Section of the Al-Cr-Si System at $800{ }^{\circ} \mathrm{C}$ and the Crystal Structure of $\tau 2$ (Cr3A19Si). J. Alloy Compd. 2007, 38, 313-318. [CrossRef]

46. Raghavan, V. Al-Si-Ti (Iron-silicon-titanium). J. Phase Equilib. Diffus. 2009, 30, 82-83. [CrossRef]

47. Vellios, N.; Tsakiropoulos, P. Study of the role of Fe and Sn additions in the microstructure of Nb-24Ti-18Si-5Cr silicide based alloys. Intermetallics 2010, 18, 1729-1736. [CrossRef]

48. Marker, M.C.; Duarte, L.I.; Leinenbach, C.; Richter, K.W. Characterisation of the Fe-rich corner of Al-Fe-Si-Ti. Intermetallics 2013, 39, 38-49. [CrossRef]

49. Gupta, S.P. Formation of intermetallic compounds in the Cr-Al-Si ternary system. Mater. Charact. 2004, 52, 255-370. [CrossRef]

50. Li, M.H.; Sun, X.F.; Li, J.G.; Zhang, Z.Y.; Jin, T.; Guan, H.R.; Hu, Z.Q. Oxidation behaviour of single-crystal Ni-base superalloy in air. I: At 800 and $900{ }^{\circ} \mathrm{C}$. Oxid. Met. 2003, 59, 591-605. [CrossRef]

51. González-Carrasco, J.L.; Garcia-Alonso, M.C.; Montealegre, M.A.; Escudero, M.L.; Chao, J. Comparative study of the alumina-scale integrity on MA 956 and PM 2000 Alloys. Oxid. Met. 2001, 55, 209-221. [CrossRef]

52. García-Alonso, M.C.; González-Carrasco, J.L.; Escudero, M.L.; Chao, J. Oxidation Behaviour of fine-grain MA 956 superalloy. Oxid. Met. 2000, 53, 77-98. [CrossRef]

53. Brumm, M.W.; Grabke, H.J. The oxidation behaviour of NiAl-I. Phase transformation s in the alumina scale during oxidation of NiAl and NiAl-Cr alloys. Corros. Sci. 1992, 33, 1677-1690. [CrossRef]

54. Novak, P.; Zelinková, M.; Šerák, J.; Michalcová, A.; Novak, M.; Vojtěch, D. Oxidation resistance of SHS $\mathrm{Fe}-\mathrm{Al}-\mathrm{Si}$ alloys at $800^{\circ} \mathrm{C}$ in air. Intermetallics 2011, 19, 1306-1312. [CrossRef]

55. Pownceby, M.I.; Constanti-Carey, K.K.; Fisher-White, M.J. Fisher-white, sub-solidus phase relationships in the system $\mathrm{Fe}_{2} \mathrm{O}_{3}-\mathrm{Al}_{2} \mathrm{O}_{3}-\mathrm{TiO}_{2}$ between $1000{ }^{\circ} \mathrm{C}$ and $1300{ }^{\circ} \mathrm{C}$. J. Am. Ceram. Soc. 2003, 86, 975-980. [CrossRef]

(C) 2019 by the authors. Licensee MDPI, Basel, Switzerland. This article is an open access article distributed under the terms and conditions of the Creative Commons Attribution (CC BY) license (http://creativecommons.org/licenses/by/4.0/). 